\title{
Early Miocene coral reef-associated bryozoans from Colombia. Part I: Cyclostomata, "Anasca" and Cribrilinoidea Cheilostomata
}

\author{
Paola Flórez, ${ }^{1,2}$ @ Emanuela Di Martino, ${ }^{3}$ ๑ and Laís V. Ramalho ${ }^{4}$ \\ ${ }^{1}$ Departamento de Estratigrafía y Paleontología, Universidad de Granada, Campus Fuentenueva s/n 18002 Granada, España <paolaflorez@ \\ correo.ugr.es> \\ ${ }^{2}$ Corporación Geológica ARES, Calle 44A No. 53-96 Bogotá, Colombia \\ ${ }^{3}$ Natural History Museum, University of Oslo, Blindern, P.O. Box 1172, Oslo 0318, Norway <e.d.martino@nhm.uio.no> \\ ${ }^{4}$ Museu Nacional, Quinta da Boa Vista, S/N São Cristóvão, Rio de Janeiro, RJ. 20940-040 Brazil <laisvr10@yahoo.com>
}

\begin{abstract}
This is the first of two comprehensive taxonomic works on the early Miocene (ca. 23-20 Ma) bryozoan fauna associated with coral reefs from the Siamaná Formation, in the remote region of Cocinetas Basin in the La Guajira Peninsula, northern Colombia, southern Caribbean. Fifteen bryozoan species in 11 families are described, comprising two cyclostomes and 13 cheilostomes. Two cheilostome genera and seven species are new: Antropora guajirensis n. sp., Calpensia caribensis n. sp., Atoichos magnus n. gen. n. sp., Gymnophorella hadra n. gen. n. sp., Cribrilaria multicostata n. sp., Cribrilaria nixor n. sp., and Figularia bragai n. sp. Eight species are identified only at genus level and remain in open nomenclature. Of the species found, $27 \%$ have erect colonies and $73 \%$ encrusting colonies. Both types contributed to the reef framework and produced sediment. The observed bryozoan diversity was higher in the barrier reefs than in the lagoonal patch reefs.
\end{abstract}

UUID: http://zoobank.org/5c8468ef-31b0-4e7e-ba93-60a2e2f30b76.

\section{Introduction}

Within a generally high marine biodiversity (Jackson and Johnson, 2001; Buzas et al., 2002), bryozoan diversity in Cenozoic tropical latitudes was also very high (Di Martino et al., 2017, 2019). In the Caribbean, a notable increase of bryozoan species richness has been recorded since the Burdigalian (ca. $18 \mathrm{Ma}$ ) (Cheetham and Jackson, 1996; Cheetham et al., 1999; O’Dea et al., 2004; Di Martino et al., 2017, 2018). However, reports of fossil bryozoans in tropical regions, especially in continental South America, remain sparse (Taylor et al., 2009; Zágoršek et al., 2014; Taylor and Waeschenbach, 2015; Ramalho et al., 2019). Diagenetic processes, which mainly affect bryozoans with aragonitic skeletons (Taylor et al., 2009), and several other factors, have undoubtedly biased against the fossil record of bryozoans in the Cenozoic tropics (Taylor and Di Martino, 2014). In addition to the limited collection effort, small bryozoan colonies tended to be overlooked in the field and inventories are therefore largely incomplete. Consequently, taxonomic studies of bryozoan faunas from the early Miocene are generally limited not only for the Caribbean/Gulf of Mexico region (e.g., Sandberg, 1962; Cheetham et al., 1999, 2007; Herrera-Cubilla and Jackson, 2014; Di Martino et al., 2017), the western Atlantic (e.g., Zágoršek et al., 2014; Ramalho et al., 2015, 2017, 2019), or the Indo-Pacific (e.g., Li, 1990; Guha and Gopikrishna, 2005, 2007; Di Martino and Taylor, 2014, 2015), but also for the more thoroughly investigated Paratethys/Mediterranean Sea (e.g., Duvergier, 1920; Buge, 1973; Nikulina and Taylor, 2010; Vávra, 2012; Di Martino and Taylor, 2017).
Despite their small size, bryozoans are a diverse group of invertebrates within marine benthic communities. Their distribution and species richness are related, in part, to the availability of hard substrata and habitat heterogeneity (Clarke and Lidgard, 2000). Coral reefs provide diverse surfaces for the settlement and growth of bryozoans, including cryptic habitats, such as caves, crevices, areas under coral colonies, rubble, and sand grains (Jackson and Winston, 1982; Choi, 1984; Ramalho et al., 2018). In addition, a high diversity of macroinvertebrates (e.g., sponges, crabs, and mollusk shells) are susceptible to colonization by bryozoans (e.g., Almeida et al., 2017; Di Martino et al., 2019). Although bryozoans are not the most abundant organisms in these tropical ecosystems in terms of biomass, their species diversity is relatively high (e.g., Santodomingo et al., 2015).

Several studies have focused on the characterization of bryozoans associated with modern coral reefs in the western central Atlantic region, and have addressed the ecological roles they play in these ecosystems (Cuffey and Kissling, 1973; Schopf, 1974; Cuffey and Fonda, 1977; Jackson and Winston, 1982; Choi, 1984; Winston, 1984, 1986; Winston and Jackson, 1984; Jackson et al., 1985). However, comprehensive taxonomic studies of bryozoan faunas in ancient coral reefs remain scarce.

The most representative taxonomic works on Caribbean Miocene bryozoans were carried out by Canu and Bassler $(1919,1923)$ in the islands of Jamaica, Hispaniola, and Cuba, as well as in Costa Rica and the federal states of Maryland, Virginia, North Carolina, and Florida (USA); by McGuirt (1941) in 


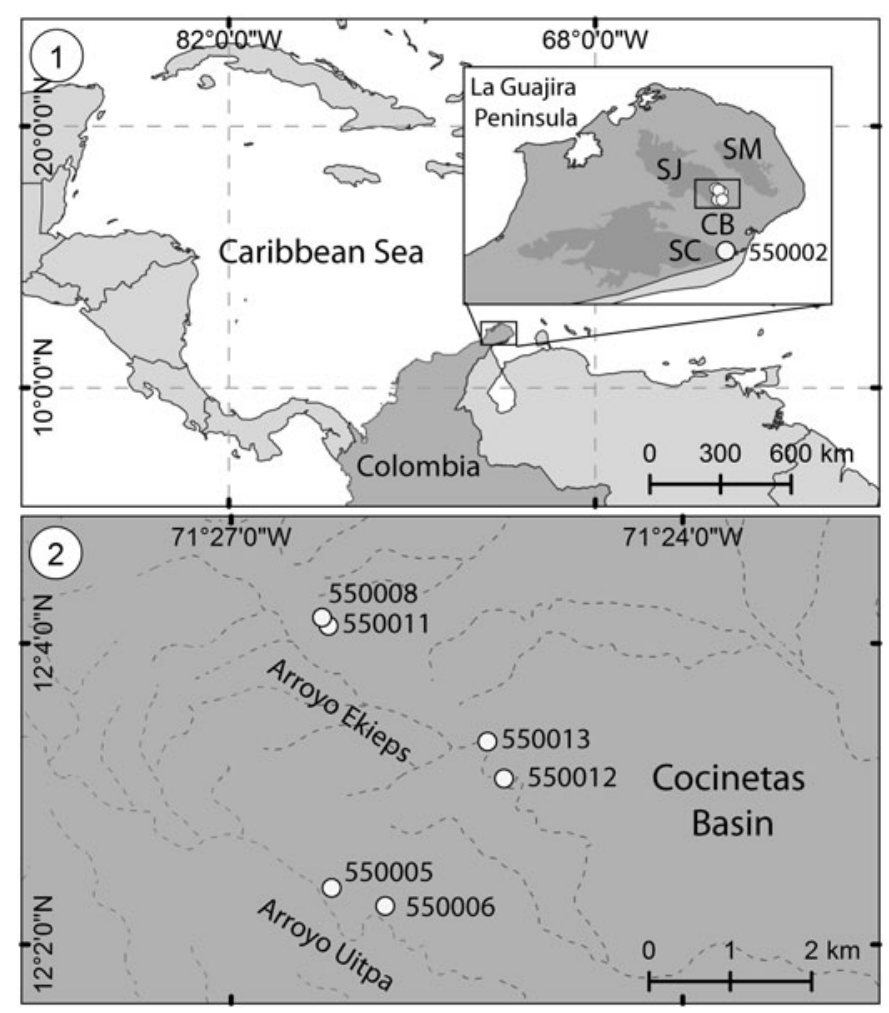

Figure 1. Locality maps. (1) Location of the La Guajira Peninsula in the Caribbean region with detail of the sampled zone showing Serranía de Cocinas (SC), Serranía de Jarara (SJ), and Serranía de Macuira (SM) surrounding the Cocinetas Basin (CB) (box), and including the locality La Flor de La Guajira (station 550002). (2) Close-up of localities Arroyo Ekieps (stations 550008, 550011, 550012, 550013) and Arroyo Uitpa (stations 550005, 550006) at the foothills of the of Serranía de Jarara in the Cocinetas Basin.

Louisiana; by Scolaro (1968) and Di Martino et al. (2017) in Florida; and by Cheetham et al. (1999) in the Dominican Republic and Panama. In Colombia, studies on fossil bryozoans are almost non-existent. Some work has been done on Devonian and Cretaceous samples (McNair, 1940; Jerez-Jaimes et al., 2013), and there are isolated mentions of "Sertella sp." and "Acanthodesia savartii form texturata" from the Miocene reefs in the oceanic island of Providencia (Buge in Geister, 1992).

The purpose of this paper is to: (1) describe the bryozoan species associated with shallow coral reefs in the Siamaná Formation (Aquitanian, ca. 23-20 Ma), thereby contributing to knowledge of bryozoan assemblages in the Caribbean Basin; (2) estimate the role played by bryozoans in reefs from the Siamaná Formation; and (3) identify the biogeographical patterns of the bryozoan fauna during the early Miocene in the southern Caribbean.

\section{Geologic setting}

The Siamaná Formation crops out in the La Guajira Peninsula (northeast Colombia), in the northeastern foothills of Serranía de Cocinas, south of Serranía de Jarara and west of Serranía de Macuira (Fig. 1) (Rollins, 1965). The formation consists of conglomerates, sandstones, and fossiliferous limestones (Renz, 1960). This formation is a diachronic sedimentary unit ranging from the late Oligocene to the early Miocene (Duque-Caro, 1974; Silva-Tamayo et al., 2017). Although the age of the upper limit of the Siamaná Formation continues to be a subject of study (Jaramillo et al., 2020), the presence of corals, such as Siderastrea siderea (Ellis and Solander, 1786) (Flórez et al., 2019b, p. 427), bivalves, such as Mimachlamys canalis (Brown and Pilsbry, 1913) (Hendy et al., 2015, p. 50), and principally the large benthic foraminifera assemblages found in the studied localities (W. Renema, personal communication, 2015) point to an early Miocene age. The early Miocene beds are mainly shallow-water marine carbonates deposited over the basement rocks of the Cocinas, Jarara, and Macuira paleoislands (Rollins, 1965, fig. 19.7; Bloch et al., 2016, fig. 4). Coral reefs grew fringing the paleoislands (Rollins, 1965; Flórez et al., 2019a, b). Deep marine siliciclastic sediments of the Uitpa Formation (Aquitanian-Burdigalian) unconformably overlie the Siamaná Formation (Renz, 1960; Hendy et al., 2015; Moreno et al., 2015). Details about the stratigraphy of the collecting localities are provided in Flórez et al. (2019a, fig. 2).

\section{Materials and methods}

The studied material was collected in the coral reef facies of the Siamaná Formation during two expeditions to the Cocinetas Basin carried out in 2011 and 2014. The bryozoan specimens were obtained from the surfaces of coral colonies and in the attached sediment. The coral samples were collected from seven stations along transects of $10 \mathrm{~m}$ (Fig. 1; Table 1). These were washed and scrubbed with a soft brush; the residual sediment was wet-sieved over mesh-sizes of 250 and $63 \mu \mathrm{m}$. In some cases, the sediment was gently removed from the corals with a needle and a paintbrush to preserve erect bryozoan fragments. To separate the encrusting colonies from the large coral substrates, when possible, small fragments of the corals were cut using a motor tool. Bryozoan specimens were cleaned using an ultrasonic bath for a few seconds to a few minutes, depending on the fragility of the colony. Coated and uncoated

Table 1. Siamaná Formation localities and stations studied in the present paper. Age is from Silva-Tamayo et al. (2017) and based on strontium isotopes in coralline algae.

\begin{tabular}{|c|c|c|c|c|}
\hline Locality & Station code & Latitude N & Longitude W & Age \\
\hline Arroyo Ekieps & 550008 & $12^{\circ} 04^{\prime} 11.02^{\prime \prime}$ & $71^{\circ} 26^{\prime} 23.09^{\prime \prime}$ & Aquitanian-Burdigalian \\
\hline Arroyo Ekieps & 550012 & $12^{\circ} 03^{\prime} 5.70^{\prime \prime}$ & $71^{\circ} 25^{\prime} 10.80^{\prime \prime}$ & Aquitanian-Burdigalian \\
\hline Arroyo Ekieps & 550013 & $12^{\circ} 03^{\prime} 20.5^{\prime \prime}$ & 71²5'18.4" & Aquitanian-Burdigalian \\
\hline Arroyo Uitpa & 550006 & $12^{\circ} 01^{\prime} 49.0^{\prime \prime}$ & $71^{\circ} 25^{\prime} 16.07^{\prime \prime}$ & Aquitanian \\
\hline Flor de La Guajira & 550002 & $11^{\circ} 49^{\prime} 52.08^{\prime \prime}$ & $71^{\circ} 23^{\prime} 58.07^{\prime \prime}$ & Aquitanian? \\
\hline
\end{tabular}


specimens were examined with scanning electron microscopy (SEM) at the "Centro de Instrumentación Científica, Universidad de Granada," employing FEI Quanta 400 and FEI Qemscan $650 \mathrm{~F}$ microscopes operating at low- and high-vacuum modes using backscattered and secondary electron detectors. Measurements of zooidal characters were made from SEM images using the image-processing program ImageJ (https://imagej.nih.gov/ ij) and are given in $\mathrm{mm}$, including mean (X), observed range (R), standard deviation (SD), and the number of measurements (N) (see tables for each species). The systematic paleontology section of Cheilostomatida follows the interim classification compiled by D.P. Gordon for the Treatise on Invertebrate Paleontology (2011). A list of collected specimens included in this study with catalog numbers, locality names, station numbers, type of colony, substrate, and number of specimens available is provided in Appendix 1. Descriptions and illustrations of the ascophoran-grade cheilostomes mentioned in the "Remarks" will be part of a separate work currently in preparation.

Repositories and institutional abbreviations.-The samples described and illustrated and the type specimens are stored in the reference collection of the Mapuka Museum of the Universidad del Norte, Barranquilla-Colombia (MUN-STRI). Type material used for comparative purposes is housed in the U.S. National Museum of Natural History, Washington, USA (USNM); Santa Barbara Museum of Natural History, Santa Barbara, USA (SBMNH); and Muséum national d'Histoire naturelle, Paris, France (MNHN).

\section{Systematic paleontology}

Order Cyclostomatida Busk, 1852a

Suborder Tubuliporina Milne-Edwards, 1838

Family Entalophoridae Reuss, 1869

Genus Mecynoecia Canu, 1918

Type species.—Entalophora proboscidea Milne-Edwards, 1838 from the Mediterranean Sea, Recent; by original designation.

Mecynoecia sp. indet.

Figure 2.1, 2.2; Table 2

Occurrence.-Early Miocene, Siamaná Formation, Arroyo Ekieps, Colombia.

Description.-Colony erect with branches circular in cross section, $\sim 0.46 \mathrm{~mm}$ in diameter. Zooids cylindrical with openings arranged in somewhat alternating whorls all around the branch, zooidal boundaries marked by narrow, thread-like, grooves. Peristomes not preserved. Frontal surface smooth, undulose, covered by moderately spaced, rounded pseudopores. Axial lumen absent. Gonozooids not observed.

Remarks. - Canu and Bassler (1920, p. 734) expanded the genus Entalophora Lamouroux, 1821 to include erect cyclostomes with cylindrical branches and zooids arranged in all directions and lacking gonozooids. However, Walter (1970) showed that species of the genus Entalophora were characterized by branches with a narrow axial lumen and subtriangular gonozooids. Based on the absence of the axial lumen, we place this poorly preserved, single branch fragment in Mecynoecia sp. indet. The lack of preserved gonozooids means that species-level identification is problematic. Mecynoecia sp. indet. was found in the sediment cemented to the scleractinian coral Goniopora hilli Vaughan, 1919.

Family Oncousoeciidae Canu, 1918

Genus Oncousoecia Canu, 1918

Type species.-Oncousoecia lobulata Canu, 1918 from the British Isles, Recent; by subsequent designation (Taylor and Zatoń, 2008).

?Oncousoecia sp. indet. Figure 2.3, 2.4; Table 3

Occurrence.-Early Miocene, Siamaná Formation, Arroyo Ekieps, Colombia.

Description.-Colony encrusting with large zooids, arranged in uni- to biserial alternating rows. Branches straight to slightly curved, apparently bifurcating. Zooids tubular (mean L/W = 1.66); zooidal boundaries not clearly demarcated. Zooidal surface densely perforated by rounded pseudopores, sometimes with transverse striations. Peristomes rising almost perpendicularly to the zooidal surface, with presumably circular to oval apertures. Gonozooids not observed.

Remarks.-Based on the encrusting and apparently bifurcating colony form, as well as relatively widely spaced and oligoserially arranged autozooids with circular apertures (Taylor and Zatoń, 2008), we tentatively attribute this specimen to Oncousoecia. The specimen from the Siamaná Formation is an incomplete, poorly preserved colony. The broken peristomes and the absence of gonozooids prevent further identification. Oncousoecia has a long fossil record from the Early Jurassic to the Recent (Taylor and Zaton, 2008). Five fossil species are known from North America: ?Oncousoecia nonomologabili Taylor and McKinney, 2006 and $O$. khirar Martha, Taylor, and Rader, 2019 from the Cretaceous of New Jersey and Texas, respectively; $O$. contortilis (Lonsdale, 1845) and $O$. bifurcata (Ulrich and Bassler, 1907) from the Paleocene of New Jersey; and O. quinqueseriata Canu and Bassler, 1920 from the Oligocene of Alabama. In addition, three Recent species are also known: $O$. abrupta and $O$. ovoidea, both described by Osburn (1953) from California, and O. arcuata Canu and Bassler, 1928 from the Gulf of Mexico. Among them, O. ovoidea, O. khirar, and ?O. nonomologabili differ from ?Oncousoecia sp. indet. in having fan-shaped colonies; $O$. bifurcata differs in having wider encrusting branches $(1.2 \mathrm{~mm}$ vs. $0.66 \mathrm{~mm})$, while $O$. quinqueseriata has narrower branches $(0.5 \mathrm{~mm})$, becomes erect, and has five longitudinal rows of autozooids. ?Oncousoecia sp. indet. resembles the early astogenetic stages of both $O$. contortilis and $O$. abrupta, but differs from the former species in having slightly curved instead of contorted branches, and from the latter Pliocene species in having wider 

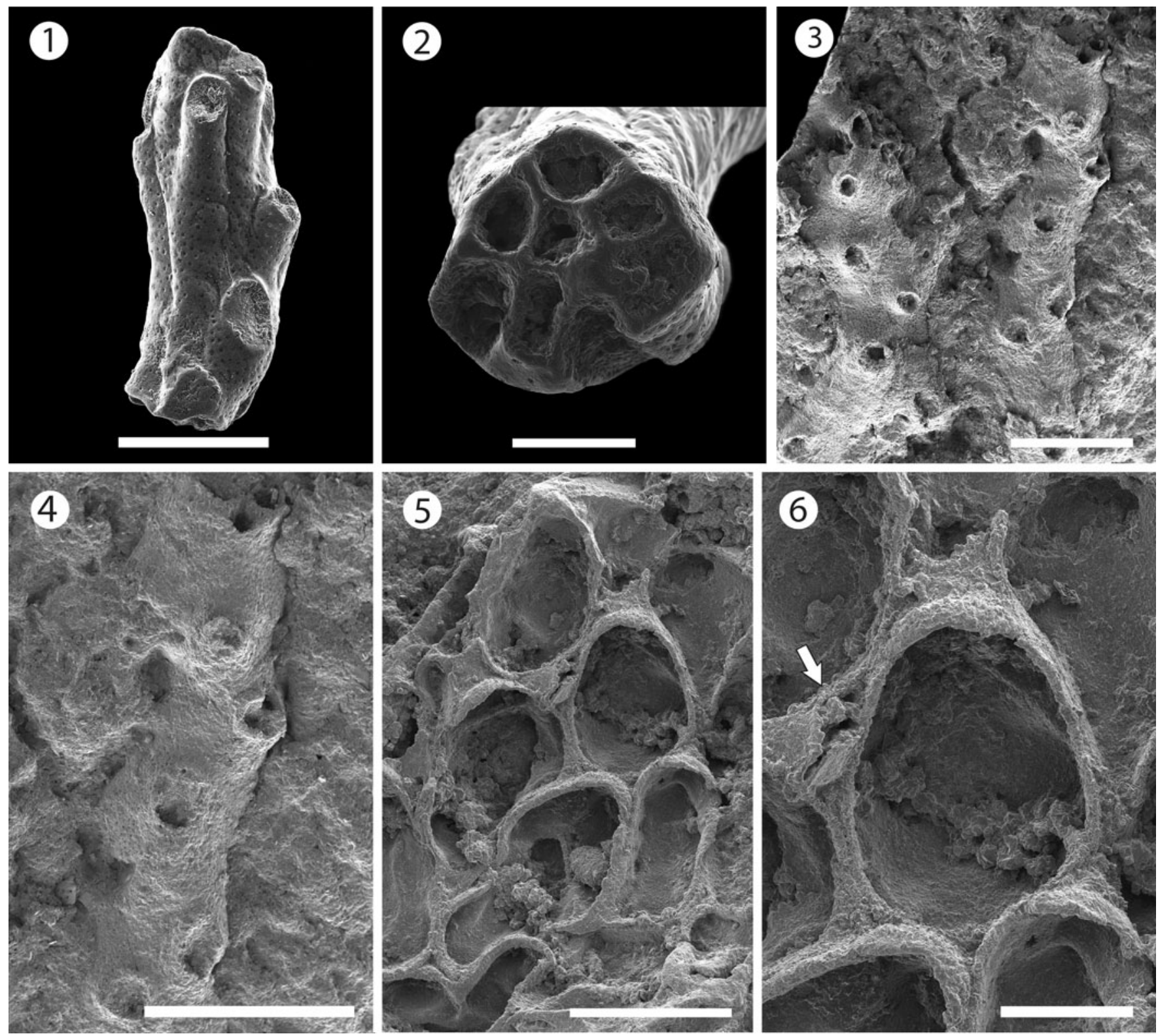

Figure 2. Mecynoecia sp. indet. (MUN-STRI-47623): (1) branch fragment; (2) view of the base of the branch fragment showing the absence of an axial lumen in cross-section. ?Oncousoecia sp. indet. (MUN-STRI-47625): (3) general view, (4) detail of the bifurcate branch. Copidozoum sp. indet. (MUN-STRI-47627): (5) general view of the colony, (6) detail of the zooid and avicularium (arrowed). All specimens are from the Siamaná Formation, Arroyo Ekieps locality. Scale bars are $(\mathbf{1}, \mathbf{5}) 0.5 \mathrm{~mm} ;(\mathbf{2}, \mathbf{6}) 0.2 \mathrm{~mm} ;(\mathbf{3}, \mathbf{4}) 1 \mathrm{~mm}$.

branches $(0.66$ vs. $0.45 \mathrm{~mm})$. Furthermore, it resembles $O$. arcuata in the shape of the branch and autozooidal arrangement, but differs in having a larger peristome diameter. ?Oncousoecia sp. indet. differs also from the European Miocene Oncousoecia biloba (Reuss, 1848) and Oncousoecia repens (Wood, 1844). The former species has multiserial and

Table 2. Measurements of Mecynoecia sp. indet. $\mathrm{X}=$ mean; $\mathrm{R}=$ observed range; $\mathrm{SD}=$ standard deviation; $\mathrm{N}=$ number of measurements .

\begin{tabular}{lcccc}
\hline Character & $\mathrm{X}$ & $\mathrm{R}$ & $\mathrm{SD}$ & $\mathrm{N}$ \\
\hline Autozooid width & 0.15 & 0.15 & 0 & 3 \\
Aperture diameter & - & 0.13 & - & 1 \\
Pseudopore diameter & 0.01 & 0.01 & 0 & 10 \\
\hline
\end{tabular}

unilamellar erect colonies (Zágoršek, 2003, 2010), while $O$. repens differs in having bi-, tri-, or multiserial branches (Busk, 1859). ?Oncousoecia sp. indet. was found, along with the ascophoran-grade cheilostome bryozoan Poricella sp., encrusting a fragment of the scleractinian coral Alveopora tampae Weisbord, 1973.

Order Cheilostomatida Busk, 1852a

Superfamily Calloporoidea Norman, 1903

Family Calloporidae Norman, 1903

Genus Copidozoum Harmer, 1926

Type species.-Membranipora plana Hincks, 1880 from Australia, Recent; by original designation. 

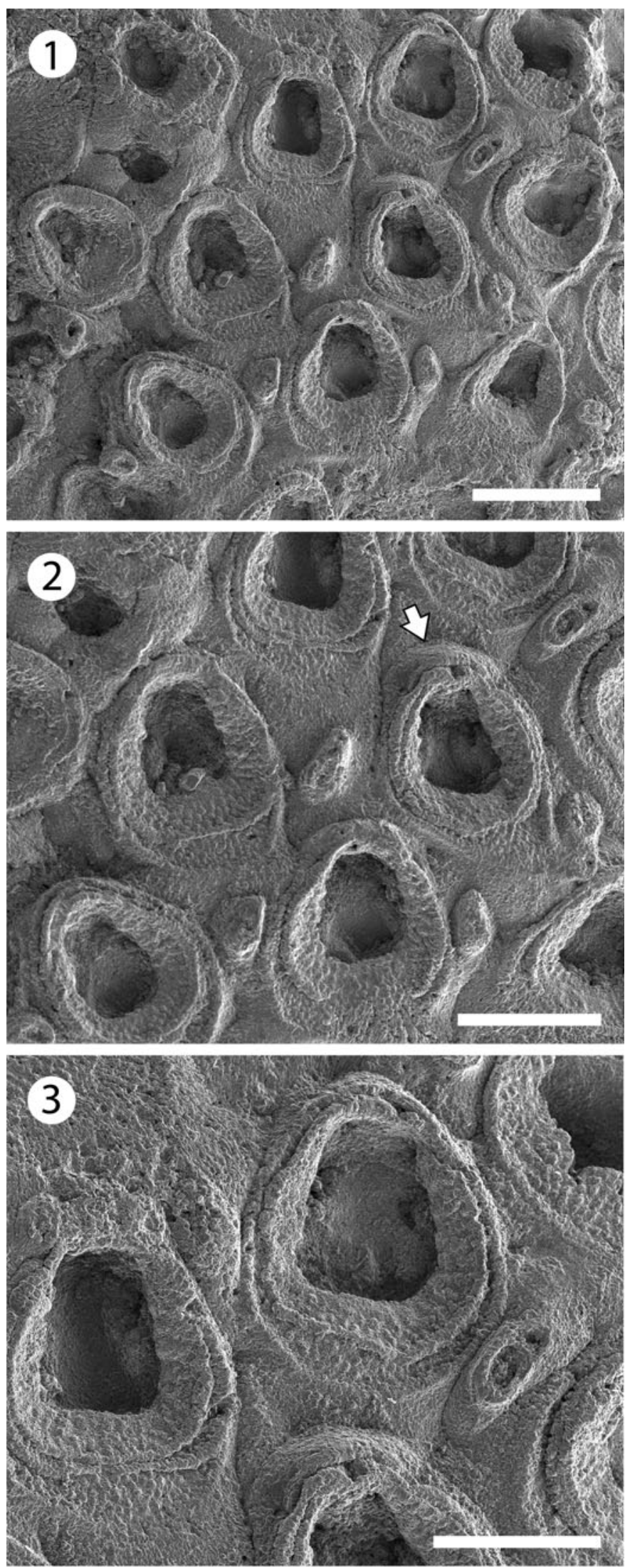

Figure 3. Antropora guajirensis n. sp. from the Siamaná Formation, Arroyo Uitpa (holotype MUN-STRI-47628): (1) general view; (2) detail of the autozooids with intramural reparative budding, drop shaped interzooidal avicularia, and cap-like ooecium (arrowed); (3) close-up of two autozooids and interzooidal avicularia. Scale bars are (1) $0.25 \mathrm{~mm}$; (2) $0.2 \mathrm{~mm}$; (3) $0.15 \mathrm{~mm}$.
Table 3. Measurements of ?Oncousoecia $\mathrm{sp}$. indet. $\mathrm{X}=$ mean; $\mathrm{R}=$ observed range; $\mathrm{SD}=$ standard deviation; $\mathrm{N}=$ number of measurements.

\begin{tabular}{lcccc}
\hline Character & $\mathrm{X}$ & $\mathrm{R}$ & $\mathrm{SD}$ & $\mathrm{N}$ \\
\hline Branch width & 0.66 & $0.62-0.77$ & 0.10 & 3 \\
Autozooid length & 0.78 & $0.67-0.9$ & 0.12 & 4 \\
Autozooid width & 0.47 & $0.39-0.55$ & 0.11 & 2 \\
Aperture diameter & 0.19 & $0.17-0.23$ & 0.03 & 6 \\
Pseudopore diameter & 0.01 & 0.01 & 0 & 10 \\
\hline
\end{tabular}

Copidozoum sp. indet.

Figure 2.5, 2.6; Table 4

Occurrence.-Early Miocene, Siamaná Formation, Arroyo Ekieps, Colombia.

Description.-Colony encrusting, unilaminar and multiserial. Zooids oval to irregular, distinctly separated by deep grooves (mean $\mathrm{L} / \mathrm{W}=1.49$ ). Opesia occupying most of the frontal surface, same shape as the zooids. Gymnocyst reduced, visible only in some zooids proximally. Cryptocyst narrow, forming a thin and elevated mural rim. A single interzooidal avicularium observed, lozenge-shaped with narrow, rounded triangular rostrum, proximolaterally directed, seemingly with pivotal condyles. Spines absent. Ancestrula and ovicells not observed.

Remarks.-Based on the characters of the interzooidal avicularium and autozooids, we place this specimen in Copidozoum. Other species of Copidozoum recorded in American Miocene deposits include $C$. parvirostris (Canu and Bassler, 1923) and C. tenuirostris (Hincks, 1880). Copidozoum sp. indet. differs from these species in having a thicker mural rim and in the orientation of the avicularia, which is distal both in C. parvirostris (Di Martino et al., 2019, p. 14, fig. 12) and C. tenuirostris (Osburn, 1950, pl. 7, fig. 4). Copidozoum sp. indet. also resembles Aplousina Canu and Bassler, 1927 in the general appearance of the autozooids; however, Aplousina lacks avicularia (Canu and Bassler, 1927, p. 3). Copidozoum sp. indet. was found growing on the basal surface of the scleractinian coral Colpophyllia willoughbiensis (Vaughan, 1919), along with the microporid Calpensia caribensis $\mathrm{n}$. sp. and the phidoloporid Rhynchozoon sp.

\section{Family Antroporidae Vigneaux, 1949 \\ Genus Antropora Norman, 1903}

Type species.—Membranipora granulifera Hincks, 1880 from Madeira, Recent; by subsequent designation (Tilbrook, 1998).

Table 4. Measurements of Copidozoum sp. indet. $\mathrm{X}=$ mean; $\mathrm{R}=$ observed range $\mathrm{SD}=$ standard deviation; $\mathrm{N}=$ number of measurements

\begin{tabular}{lcccc}
\hline Character & $\mathrm{X}$ & $\mathrm{R}$ & $\mathrm{SD}$ & $\mathrm{N}$ \\
\hline Opesia length & 0.49 & $0.46-0.55$ & 0.04 & 4 \\
Opesia width & 0.28 & $0.19-0.34$ & 0.08 & 3 \\
Autozooid length & 0.51 & $0.39-0.56$ & 0.08 & 4 \\
Autozooid width & 0.34 & $0.25-0.4$ & 0.08 & 3 \\
Avicularium length & - & 0.21 & - & 1 \\
Avicularium width & - & 0.08 & - & 1 \\
Ooecium length & 0.05 & $0.04-0.05$ & 0.01 & 3 \\
Ooecium width & 0.2 & 0.2 & 0 & 3 \\
\hline
\end{tabular}


Table 5. Measurements of Antropora guajirensis n. sp. X = mean; $\mathrm{R}=$ observed range; $\mathrm{SD}=$ standard deviation; $\mathrm{N}=$ number of measurements.

\begin{tabular}{lcccc}
\hline Character & $\mathrm{X}$ & $\mathrm{R}$ & $\mathrm{SD}$ & $\mathrm{N}$ \\
\hline Autozooid length & 0.36 & $0.31-0.43$ & 0.04 & 10 \\
Autozooid width & 0.26 & $0.25-0.28$ & 0.01 & 12 \\
Opesia length & 0.15 & $0.13-0.16$ & 0.01 & 14 \\
Opesia width & 0.12 & $0.11-0.13$ & 0.01 & 10 \\
Avicularium length & 0.09 & $0.08-0.12$ & 0.01 & 11 \\
Avicularium width & 0.05 & 0.05 & 0 & 10 \\
Ooecium length & 0.04 & $0.03-0.04$ & 0.01 & 2 \\
Ooecium width & 0.16 & $0.15-0.17$ & 0.01 & 2 \\
\hline
\end{tabular}

Antropora guajirensis new species Figure 3; Table 5

Holotype.-MUN-STRI-47628, from the early Miocene Siamaná Formation, Arroyo Uitpa, La Guajira, Colombia.

Diagnosis.-Colony encrusting. Zooids oval to elliptical with oval to pear-shaped opesia. Gymnocyst smooth, developed proximally. Cryptocyst granular, surrounding the opesia, tapering distally. Interzooidal avicularia elliptical to drop-shaped, randomly placed, oriented distolaterally. Ooecium cap-like, imperforate.

Description.-Colony encrusting, multiserial, and unilaminar. Zooids distinctly separated by deep grooves, oval to elliptical in shape (mean $\mathrm{L} / \mathrm{W}=1.37$ ), sometimes polygonal where the proximal gymnocystal area is more extensive. Opesia oval to pear-shaped, occupying half to two-thirds of the frontal surface. Gymnocyst smooth, more developed proximally and surrounding the cryptocyst. Cryptocyst granular, extended proximally, narrowing progressively laterally, tapering distally. Avicularia interzooidal, elliptical to drop-shaped with rounded rostrum, oriented distolaterally, and arranged randomly within the colony. Ovicells endozooidal; ooecium small, cap-like, smooth, and imperforate. Intramural reparative budding common. Large vicarious avicularia not observed.

Etymology.—Named after the La Guajira Peninsula, in reference to the region where it was collected for the first time, plus the Latin suffix -ensis, meaning originating in.

Remarks.-Canu and Bassler $(1917$, p. 17, 28) introduced the genera Membrendoecium and Dacryonella for some American fossil species; however, both genera have been regarded as junior synonyms of Antropora (Bassler, 1953; Tilbrook, 1998). Among the American fossil species of Antropora, the late Pliocene Antropora parvicapitata (Canu and Bassler, 1923) differs from A. guajirensis n. sp. in having small rounded kenozooids between the zooids and a single median tubercle in the proximal gymnocyst (Taylor and Foster, 1998, p. 66, figs. 5, 6; Di Martino et al., 2017, p. 108, figs. 8b, c). Antropora lowei (Canu and Bassler, 1920) from the Oligocene differs in having small, but frequent, indistinct "avicularia," which in fact could be "interopesial cavities" between the zooids (Canu and Bassler, 1920, p. 121, pl. 81, fig. 1). The Recent $A$. typica Canu and Bassler (1928) differs in having a pair of small interzooidal avicularia placed at the distal end of most autozooids and oriented distally (Tilbrook, 1998), while the new species has interzooidal avicularia oriented distolaterally, placed randomly. In the Siamaná Formation, it was found encrusting the rubble of Porites sp., and co-existing with the bryozoans Gymnophorella hadra n. gen. n. sp. and ?Hippopleurifera sp. 1.

\author{
Family Quadricellariidae Gordon, 1984 \\ Genus Nellia Busk, 1852
}

Type species.—Cellaria tenella (Lamarck, 1816) from Austral seas (?), Recent; by subsequent designation (Busk, 1852b).

Nellia cf. N. tenella (Lamarck, 1816)

Figure 4.1-4.3; Table 6

cf. 1816 Cellaria tenella Lamarck, p. 135.

cf. 1920 Nellia oculata; Canu and Bassler, p. 196, pl. 82, figs. 6-10.

cf. 1984 Nellia tenella; Winston and Cheetham, p. 257, figs. 1, 2. cf. 2017 Nellia tenella; Di Martino et al., p. 109, fig. 9.

cf. 2019 Nellia tenella; Ramalho et al., p. 111, figs. 2a-c.

Syntypes.-MNHN-IB-2008-4546, MNHN-IB-2008-5255, Southern seas (?), Recent.

Occurrence.-?Late Cretaceous to Recent. The oldest record is from the Maastrichtian of Jamaica (Cheetham, 1968). Eocene Crystal River Formation, Florida, USA (Winston and Cheetham, 1984). Eocene Upper Bracklesham Beds, England; France, Spain, and Senegal (Cheetham, 1966). Oligocene Chickasawhay Formation, Alabama, USA (Winston and Cheetham, 1984). Early Miocene Pirabas Formation, Pará State, Brazil (Ramalho et al., 2019) and Arroyo Ekieps, Siamaná Formation, Colombia. Late Miocene Cercado Formation, Dominican Republic (Winston and Cheetham, 1984). Miocene from Egypt and Australia (Cheetham, 1966). Recent, widespread in tropical and warm-temperate waters (Cheetham, 1966).

Description.-Colony erect, articulated. Branches narrow, quadriserial, squared in cross-section. Zooids arranged in four longitudinal rows, in alternate positions with their lateral neighbors. Zooids distinct, delimited by a slender groove, all similar in size, elongate and sub-rectangular in shape. Opesia oval, occupying most of the frontal surface. Gymnocyst smooth, extended proximally and reduced laterally and distally. Cryptocyst smooth, forming a rim around the opesia. Mural rim slightly raised. Two small, elliptical avicularia placed in the proximal corners of the gymnocyst of each zooid, with a circular rootlet pore below the raised rostrum. Autozooids located at the tip of the internode tapering proximally. Ooecium not observed.

Remarks. - The internode fragments available in our material are poorly preserved and lack ooecia, preventing species-level identification. However, they resemble Nellia tenella in the characteristic arrangement and shape of the autozooids and avicularia. The specimens from the Siamaná Formation are similar to those from the Miocene of the Dominican Republic 

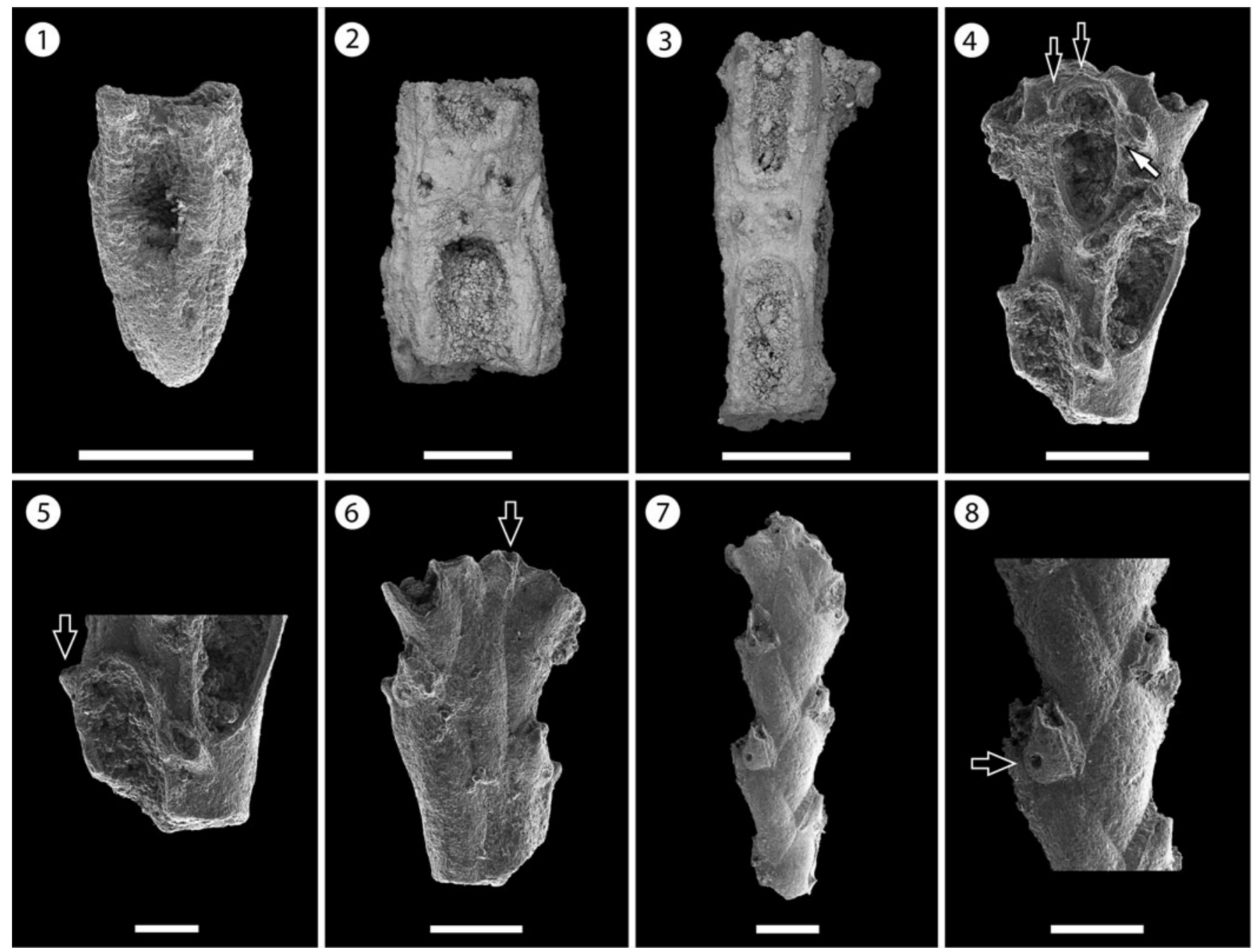

Figure 4. Nellia cf. N. tenella (Lamarck, 1816) (MUN-STRI-47630): (1) part of a tapering zooid at the tip of the branch, (2) paired elliptical avicularia, (3) branch fragment with incomplete zooids. Licornia sp. indet. (MUN-STRI-47632): (4) frontal view of the branch at bifurcation showing the breaking point of the nodal joint crossing through the proximal part of the zooid, two distal spine bases (black arrows), and the insertion of the scutum (white arrow); (5) frontal view of the branch with the lateral (arrowed) and frontal avicularia; (6) abfrontal view of the branch at bifurcation showing the single axial vibraculum (arrowed); (MUN-STRI-47633): (7) abfrontal view of a branch fragment showing the vibracular chambers; $(\mathbf{8})$ detail of the vibracular chamber showing the straight setal groove and the rhizoidal pore (black arrow). All specimens are from the Siamaná Formation, Arroyo Ekieps locality. Scale bars are (1, 3, 4, 6) $0.2 \mathrm{~mm} ;(\mathbf{2}, \mathbf{8}) 1 \mathrm{~mm} ;(\mathbf{5}) 0.1 \mathrm{~mm} ;(\mathbf{7}) 0.25 \mathrm{~mm}$.

figured by Winston and Cheetham (1984, fig. 2D). However, the size of the opesia in these fragments is smaller than those of the Dominican specimens, as well as the syntype (MNHN-IB-2008-4546), and other specimens from different regions and ages (Cheetham, 1963, 1966; Winston et al., 2014; Di Martino et al., 2017). Although Winston and Cheetham (1984) suggested that the variation in size is not significant, and proposed to consider $N$. tenella as a living fossil, based on the results of the statistical analyses performed on specimens ranging from the Late Cretaceous to the Recent, certain

Table 6. Measurements of Nellia $\mathrm{cf}$. $N$. tenella. $\mathrm{X}=$ mean; $\mathrm{R}=$ observed range; $\mathrm{SD}=$ standard deviation; $\mathrm{N}=$ number of measurements.

\begin{tabular}{lcccr}
\hline Character & $\mathrm{X}$ & $\mathrm{R}$ & $\mathrm{SD}$ & $\mathrm{N}$ \\
\hline Autozooid width & 0.14 & $0.12-0.16$ & 0.02 & 4 \\
Opesia width & 0.07 & $0.06-0.08$ & 0.01 & 5 \\
Avicularium length & 0.05 & $0.04-0.06$ & 0.01 & 4 \\
Avicularium width & 0.04 & $0.03-0.04$ & 0.01 & 4 \\
\hline
\end{tabular}

characters, which could reveal differences between localities and periods, such as ooecium morphology, have seldom been recorded. New fossil collections and phylogenetic studies using Recent material are needed to confirm its living-fossil status or to reveal that it is a species complex.

"Nellia tenella" was very common in the Miocene (Winston and Cheetham, 1984). Its Recent distribution is circumtropical to subtropical and it has been recorded on coral reefs (Winston, 1986). In the Siamaná Formation, $N$. cf. $N$. tenella was found in the sediment cemented to the scleractinian coral Goniopora hilli, co-occurring with the bryozoan Poricellaria sp. (as also observed in other fossil and recent localities and environments, e.g., intertidal rocks; Winston and Cheetham, 1984), Margaretta sp., Ditaxiporina sp., and Mecynoecia sp.

Superfamily Buguloidea Gray, 1848 Family Candidae d'Orbigny, 1851 Genus Licornia van Beneden, 1850 
Type species.-Acamarchis jolloisii Audouin, 1826 from Red Sea, Recent; by original designation.

\section{Licornia sp. indet.}

Figure 4.4-4.8; Table 7

Occurrence.-Early Miocene, Siamaná Formation, Arroyo Ekieps, Colombia.

Description.-Colony erect, articulated. Branches flat, elliptical in cross-section. Zooids distinct, biserial, alternately arranged, sub-rectangular in shape (mean $\mathrm{L} / \mathrm{W}=2.97$ ). Opesia oval, with a raised mural rim, occupying two-thirds of the frontal surface. ?Two distal spine bases. Base of the scutum arising from the distal third of the inner side of the opesia, next to the frontal avicularium of the adjacent zooid. Gymnocyst smooth, well developed proximally, tapering laterally and distally around the opesia. Avicularia adventitious, frontal, and lateral; frontal avicularia placed proximally immediately below the rim of the opesia, monomorphic, frequent, with a proximally raised, rounded rostrum, proximolaterally directed towards the exterior; lateral avicularia smaller than frontal avicularia, located on the outer distal corner of each autozooid, triangular. Abfrontal surface smooth. Vibracular chamber trapezoidal with rhizoidal pore and straight setal groove, directed obliquely to the internodal axis, occupying two-thirds of the length of the vibracular chamber. Nodal joints crossing the proximal opesia of the outer zooids and below the opesia of the inner zooids at the bifurcation. Single axial vibraculum in the bifurcation, with straight setal groove and lacking a rhizoidal pore. Ooecium not observed. Scutum and spines not preserved.

Remarks.-We place these specimens in the genus Licornia based on the position of the joint crossings, the straight rostrum of the lateral avicularia, the oblique setal groove of the vibracular chambers, and the single axial vibraculum. The closest allied genus, Paralicornia Vieira et al., 2014, differs in having an opesia occupying only half of the total length of the zooids and a shorter setal groove.

North American Cenozoic species of Licornia include Canu and Bassler's (1920) L. cookei, L. milneri, and L. resseri, all known from the Oligocene. Licornia sp. indet. differs from these species in the morphology and size of the frontal and lateral avicularia: L. cookei has rounded lateral avicularia, L. milneri has very large and acuminate frontal avicularia, and

Table 7. Measurements of Licornia sp. indet. $\mathrm{X}=$ mean; $\mathrm{R}=$ observed range; $\mathrm{SD}=$ standard deviation; $\mathrm{N}=$ number of measurements.

\begin{tabular}{lcccc}
\hline Character & $\mathrm{X}$ & $\mathrm{R}$ & $\mathrm{SD}$ & $\mathrm{N}$ \\
\hline Autozooid length & 0.50 & $0.47-0.52$ & 0.03 & 3 \\
Autozooid width & 0.17 & $0.16-0.2$ & 0.02 & 6 \\
Opesia length & 0.27 & $0.26-0.28$ & 0.01 & 3 \\
Opesia width & 0.11 & $0.10-0.11$ & 0.01 & 4 \\
Avicularium frontal length & 0.07 & 0.07 & 0 & 3 \\
Avicularium frontal width & 0.04 & $0.03-0.05$ & 0.01 & 4 \\
Avicularium lateral length & 0.05 & $0.04-0.05$ & 0.01 & 2 \\
Avicularium lateral width & 0.02 & $0.02-0.03$ & 0.01 & 3 \\
Vibracular chamber length & 0.17 & $0.14-0.2$ & 0.02 & 10 \\
Rhizoidal pore diameter & 0.03 & 0.03 & 0 & 6 \\
\hline
\end{tabular}

L. resseri has very large lateral avicularia. Licornia regularis (Osburn, 1940), known in the Caribbean region from the Pleistocene to Recent, differs in having larger vibracular chambers reaching half of the total length of the zooids, frontal avicularia with triangular rostrum, lateral avicularia with serrated rostrum, and squatter zooids (Winston, 2005, p. 27, figs. 63-68). Other Recent tropical Western Atlantic species, such as L. drachi (Marcus, 1955) and L. micheli (Marcus, 1955), differ from Licornia sp. indet. in having a larger opesia that covers almost the whole frontal surface of the zooids, and lateral avicularia of variable size, sometimes as long as the opesia.

The scarcity of material, as well as the absence of diagnostic features, such as ooecia, spines, and scuta, prevent species-level identification. In the Siamaná Formation, the fragments of Licornia sp. indet. were found in the sediment cemented to the coral Acropora panamensis Vaughan, 1919, co-occurring with other erect bryozoans including Ditaxiporina sp., Catenicella sp., and Margaretta sp.

\section{Superfamily Microporoidea Gray, 1848 \\ Family Microporidae Gray, 1848 \\ Genus Calpensia Jullien, 1888}

Type species.-Membranipora calpensis Busk, 1854 from the Mediterranean Sea, Recent; by original designation.

\section{Calpensia caribensis new species \\ Figure 5.1-5.3; Table 8}

Holotype.-MUN-STRI-47635. Paratypes: MUN-STRI-47634, MUN-STRI-47636. From the early Miocene Siamaná Formation, Arroyo Ekieps, La Guajira, Colombia.

Diagnosis.-Colony encrusting, multiserial. Zooids sub-rectangular with semicircular orifice, placed over the raised opercular region. Cryptocyst granular, densely perforated (>100 pseudopores). Two symmetrical, elliptical opesiules, placed proximolaterally to the orifice.

Description.-Colony encrusting, multiserial, unilaminar. Zooids separated by a suture on a raised mural rim, elongate and sub-rectangular in shape (mean $\mathrm{L} / \mathrm{W}=1.58$ ), widening at about mid-length and arranged in alternating, longitudinal rows. Orifice terminal, semicircular with a straight proximal margin; opercular region slightly developed. Cryptocyst flat proximally, depressed towards the opesiular area at about two-thirds of zooidal length, and raised distally; granular surface, densely and evenly perforated with up to $\sim 110-120$ circular pseudopores, absent in the area surrounding the opesia and between the opesia and the opesiules; pseudopores $\sim 5 \mu \mathrm{m}$ in diameter. Mural rim raised and crenulated. Two elliptical opesiules, longer than wide, equal in size, located proximolaterally at about two-thirds of zooidal length, $\sim 0.14$ $\mathrm{mm}$ below the opesia.

Etymology.-From the Caribbean Sea, in reference to the biogeographic region that the new species inhabited, plus the Latin suffix -ensis meaning originating in. 

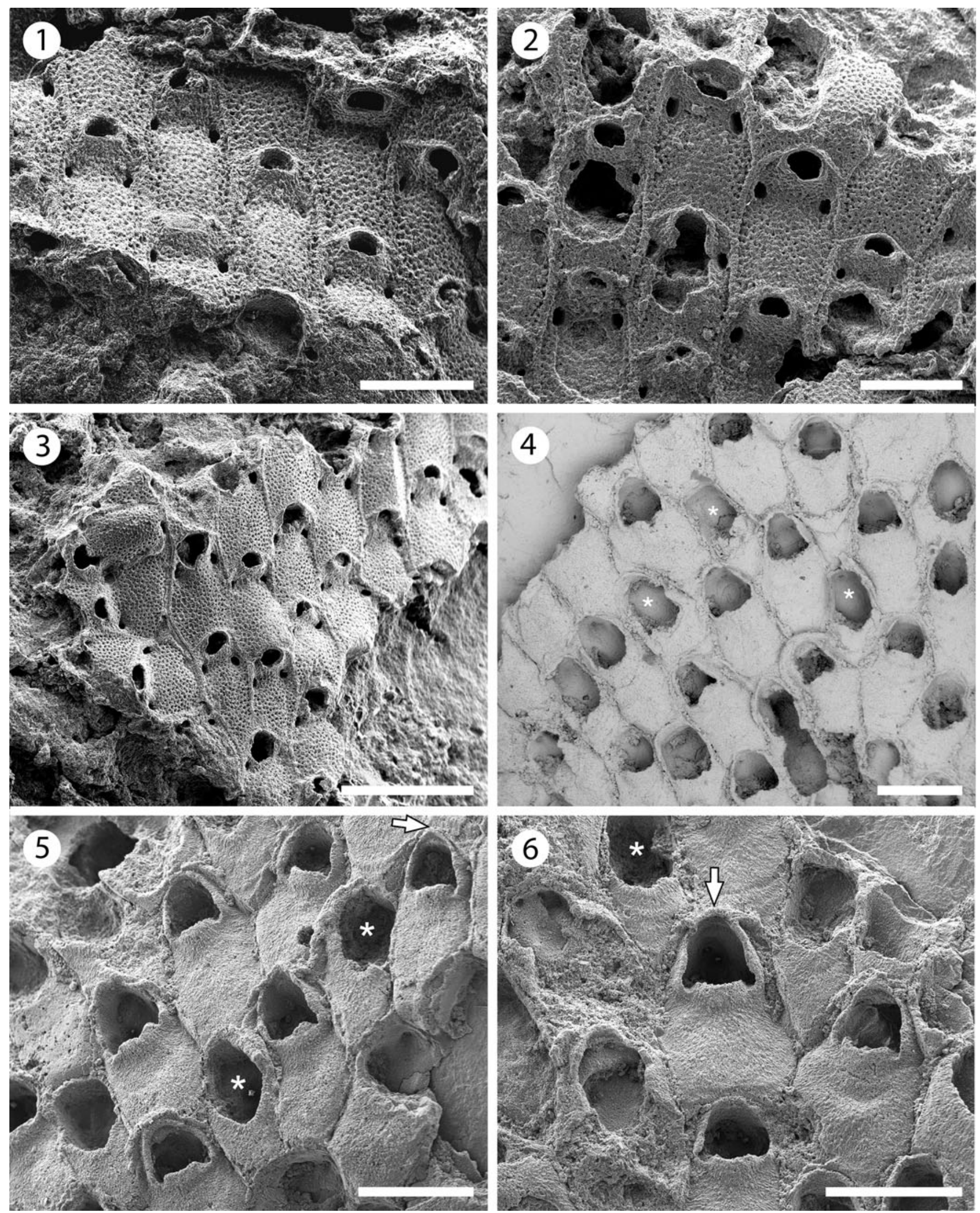

Figure 5. Calpensia caribensis n. sp. from the Siamaná Formation, Arroyo Ekieps (holotype MUN-STRI-47635): (1) autozooids showing the semicircular opesia and the proximally raised opercular region, (2) close-up of autozooids showing paired opesiules, (3) general view of the colony. Atoichos magnus n. gen. n. sp. from the Siamaná Formation, Arroyo Ekieps (holotype MUN-STRI-47637); asterisks indicate putative avicularia: (4) group of autozooids, (5) oblique view showing the development and shape of the cryptocyst and the distal raised opesial margin (arrowed), (6) zooids showing well-preserved opesia with opesiular indentations and the distal opesial margin (arrowed). Scale bars are $(\mathbf{1}, \mathbf{2}, \mathbf{4 - 6}) 0.5 \mathrm{~mm} ;(\mathbf{3}) 1 \mathrm{~mm}$. 
Table 8. Measurements of Calpensia caribensis $\mathrm{n}$. sp. $\mathrm{X}=$ mean; $\mathrm{R}=$ observed range; $\mathrm{SD}=$ standard deviation; $\mathrm{N}=$ number of measurements.

\begin{tabular}{lcccc}
\hline Character & $\mathrm{X}$ & $\mathrm{R}$ & $\mathrm{SD}$ & $\mathrm{N}$ \\
\hline Autozooid length & 0.67 & $0.62-0.75$ & 0.05 & 11 \\
Autozooid width & 0.43 & $0.38-0.49$ & 0.03 & 16 \\
Opesia length & 0.09 & $0.08-0.1$ & 0.01 & 10 \\
Opesia width & 0.15 & $0.14-0.18$ & 0.01 & 13 \\
Opesiule length & 0.08 & $0.05-0.11$ & 0.02 & 11 \\
Opesiule width & 0.05 & $0.04-0.06$ & 0.01 & 11 \\
Pores number & 116 & $98-144$ & 16.85 & 6 \\
\hline
\end{tabular}

Remarks. - The specimens of Calpensia caribensis n. sp. found in the Siamaná Formation resemble specimens of the Recent Mediterranean Calpensia nobilis (Esper, 1797). Calpensia nobilis is commonly found in the late Miocene to the Recent of the Mediterranean (Hayward and McKinney, 2002; Moissette et al., 2007). Canu and Bassler (1923) identified specimens of Calpensia as C. impressa (Moll, 1803) in the Oligocene of the southern Caribbean, which were subsequently attributed to $C$. nobilis by Buge (1957). The new species is similar to Mediterranean specimens of C. nobilis in the size of the opesia and opesiules (Hayward and McKinney, 2002 , p. 31, fig. $13 \mathrm{a}-\mathrm{c}$ ), as well as in the mean ratios of opesia length/zooid length (0.13 vs. 0.12$)$, and opesia width/ zooid width (0.36 vs. 0.39). However, C. caribensis n. sp. has squatter autozooids (zooid length $0.67 \mathrm{~mm}$ vs. $0.82 \mathrm{~mm}$; zooid width $0.43 \mathrm{~mm}$ vs. $0.38 \mathrm{~mm}$ ). Although Canu and Bassler (1930) and Buge (1957) reported wide variations of the size of the zooids in this species, the mean ratio of zooid length/ zooid width between our specimens and Recent material differs greatly (1.58 vs. 2.15 ), indicating a different zooidal shape. In addition, the Siamaná Formation specimens have a greater number of pseudopores in the cryptocyst (almost twice as many; mean of pores number 116 vs. 61). Based on these differences, as well as the spatial and temporal distance between the two populations, we introduce this new species. In the Siamaná Formation, Calpensia caribensis n. sp. was found encrusting coralline algae covering the coral Alveopora tampae and on the basal surface of the coral Colpophyllia willoughbiensis, while small detached fragments were scattered in the sediment associated with Goniopora hilli. In our material, Calpensia caribensis n. sp. co-occurs with Copidozoum sp., Gemelliporidra sp., and Rhynchozoon sp.

Family Onychocellidae Jullien, 1882

Genus Atoichos new genus

Type species.-Atoichos magnus n. gen. n. sp., from Arroyo Ekieps, Colombia, early Miocene, Siamaná Formation; by monotypy.

Diagnosis.—As the type species by monotypy.

Etymology.-From the Greek privative prefix $a$ - and toichos (masculine), meaning wall, alluding to the absence of a raised mural rim surrounding the autozooids.

Remarks.-We place Atoichos n. gen. in the family Onychocellidae because of its extensive cryptocyst, the bell-shaped opesia with opesiular identations, the probable presence of vicarious avicularia, and the absence of a gymnocyst and spines (Taylor et al., 2018). Atoichos n. gen. resembles in general appearance the genus Steraechmella Lagaaij, 1952, belonging to the family Microporidae Gray, 1848, which is commonly allied with Onychocellidae (Taylor et al., 2018). It differs in having wider opesia and, as in remaining genera of this family, in lacking a raised margin around the proximal two-thirds of the zooid. The poor preservation of the single specimen available prevents a detailed description of the morphology of the putative vicarious avicularia (i.e., opesia and rostrum), which could alternatively be narrower autozooids placed at row bifurcations where two regular zooids sometimes occupy the same width of the one preceding them in the row. However, as observed in some calloporids in the studies carried out by Cook (1968) on the Recent genus Crassimarginatella Canu, 1900 and by Cheetham et al. (2006) on the fossil genus Wilbertopora Cheetham, 1954, the morphology of avicularia is variable, some involving only slight modifications of the autozooids. In some onychocellids (e.g., Euritina Canu, 1900) interzooidal avicularia are similar to autozooids, although smaller (Taylor et al., 2018, p. 1676, fig. 10).

\section{Atoichos magnus new species Figure 5.4-5.6; Table 9}

Holotype.-MUN-STRI-47637, from the early Miocene Siamaná Formation, Arroyo Ekieps, La Guajira, Colombia.

Diagnosis.-Colony encrusting, multiserial, uni- to multilaminar. Zooids rhomboidal to elliptical, defined by a raised opesial margin distally and a deep groove proximolaterally. Opesia terminal, triangular to bell-shaped, as long as wide, occupying the distal third of the frontal surface; opesiular indentations shallow; proximal edge projected, straight to slightly curved. Cryptocyst extensive, granular, flat to slightly convex. Gymnocyst absent. Putative vicarious avicularia narrower than regular zooids; rounded triangular, commonly located at row bifurcations; opesia poorly preserved. Ovicells unknown.

Description.-Colony encrusting, multiserial, uni- to multilaminar. Early astogenetic stages apparently fan-shaped. Zooids distinct, elongate, rhomboidal, to elliptical (mean L/W $=1.74$ ), separated distally by a raised opesial margin, and a fine and deep groove proximo-laterally. Opesia terminal, wide,

Table 9. Measurements of Atoichos magnus n. gen. n. sp. X= mean; $\mathrm{R}=$ observed range; $\mathrm{SD}=$ standard deviation; $\mathrm{N}=$ number of measurements.

\begin{tabular}{lcccc}
\hline Character & $\mathrm{X}$ & $\mathrm{R}$ & $\mathrm{SD}$ & $\mathrm{N}$ \\
\hline Autozooid length & 0.74 & $0.57-0.93$ & 0.09 & 19 \\
Autozooid width & 0.43 & $0.31-0.83$ & 0.12 & 17 \\
Opesia length & 0.22 & $0.16-0.28$ & 0.03 & 15 \\
Opesia width & 0.20 & $0.17-0.23$ & 0.02 & 11 \\
Interzooidal avicularium length & 0.63 & $0.49-0.72$ & 0.08 & 11 \\
Interzooidal avicularium width & 0.32 & $0.26-0.4$ & 0.04 & 10 \\
Avicularian opesia length & 0.37 & $0.35-0.38$ & 0.02 & 3 \\
Avicularian opesia width & 0.23 & $0.22-0.24$ & 0.01 & 3 \\
\hline
\end{tabular}


triangular to bell-shaped, as long as wide; borders raised forming a lateral furrow between the opesia margin and the adjacent zooids; opesiular indentations located at the proximolateral corners, slightly constricted laterally, proximal edge projecting distally with straight to slightly concave margin. Cryptocyst granular, occupying two-thirds of the frontal surface, flat to slightly convex, narrow laterally to the opesia. Putative vicarious avicularia narrower and slightly shorter than ordinary feeding zooids, rounded triangular, commonly located at longitudinal row bifurcations; opesia poorly preserved, ?oval, occupying more than half of the frontal surface, rostrum extended but broken, observed only twice, probably rounded (Fig. 5.4). Ovicells not observed.

Etymology.-From the Latin magnus, large, in reference to the large size of the autozooids.

Remarks. - The single colony found in the Siamaná Formation exhibits signs of dissolution. However, its morphological features are well preserved enough to allow comparisons with other genera and species in the family Onychocellidae. Atoichos magnus n. gen. n. sp. resembles species of Aechmella Canu and Bassler, 1917 and Aechmellina Taylor, Marta, and Gordon, 2018. Aechmella differs in having smaller interzooidal avicularia, about half the width of the zooids with an acutely triangular rostrum, while Aechmellina differs in having frequent, small interzooidal avicularia with a pointed rostrum. Atoichos magnus n. gen. n. sp. also resembles Floridinella vicksburgica Canu and Bassler, 1917 in having a wide opesia, but differs in having kenozooids and avicularia with a triangular rostrum oriented laterally (Cook and Bock, 2001, p. 547). In the Siamaná Formation, Atoichos magnus n. gen. n. sp. was found encrusting a mollusk shell, sharing the substrate with Glabrilaria sp. indet. and a poorly preserved cyclostome.

Genus Smittipora Jullien, 1882

Type species._-Vincularia abyssicola Smitt, 1873 from Cuba and Florida, USA, Recent; by original designation.

\section{Smittipora sp. indet.}

Figure 6; Table 10

Occurrence.-Early Miocene, Siamaná Formation, Arroyo Uitpa, Colombia.

Description.-Colony encrusting, multiserial, unilaminar. Zooids defined by a raised rim, sub-hexagonal, rounded distally (mean $\mathrm{L} / \mathrm{W}=1.32$ ). Opesia subterminal, bell-shaped, with proximolateral indentations outlining a tongue-like process medially, occupying half to one-third of the total length of the zooid. Cryptocyst extensive, depressed, flat, and coarsely granular. Vicarious avicularia symmetrical, similar in length to autozooids, but about half of their width, rounded rhomboidal; opesia reversed pear-shaped; cryptocyst granular. Ovicellate zooids with the distal edge formed by the 'cryptocyst' of the distal zooid; fertile zooids slightly longer than non-fertile autozooids.
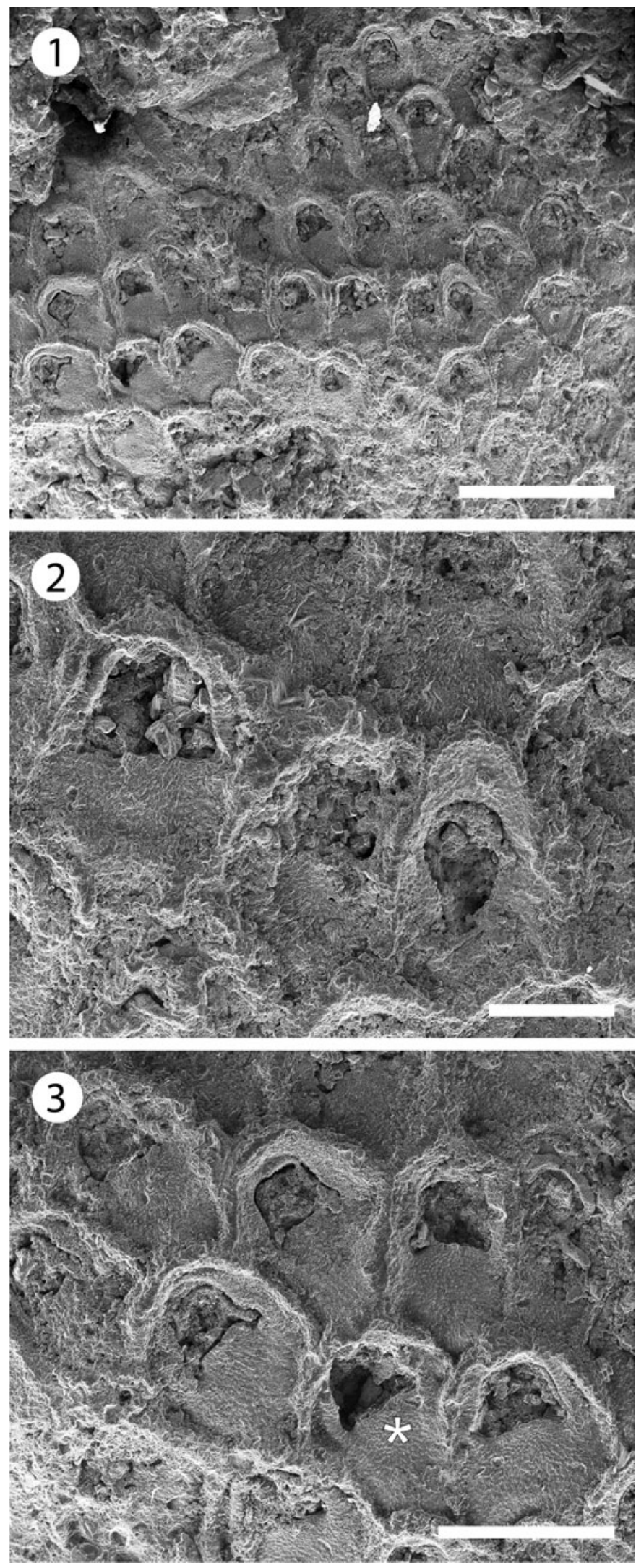

Figure 6. Smittipora sp. indet. from the Siamaná Formation, Arroyo Uitpa (MUN-STRI-47638): (1) general view of the colony, (2) two zooids and a vicarious avicularium with round rostrum, (3) close-up of autozooids and a fertile zooid (asterisk). Scale bars are (1) $1 \mathrm{~mm}$; (2) $0.25 \mathrm{~mm}$; (3) $0.5 \mathrm{~mm}$. 
Table 10. Measurements of Smittipora $\mathrm{sp}$. indet. $\mathrm{X}=$ mean; $\mathrm{R}=$ observed range; $\mathrm{SD}=$ standard deviation; $\mathrm{N}=$ number of measurements.

\begin{tabular}{lcccc}
\hline Character & $\mathrm{X}$ & $\mathrm{R}$ & $\mathrm{SD}$ & $\mathrm{N}$ \\
\hline Autozooid length & 0.57 & $0.5-0.65$ & 0.03 & 17 \\
Autozooid width & 0.43 & $0.36-0.51$ & 0.05 & 18 \\
Opesia length & 0.21 & $0.18-0.25$ & 0.02 & 7 \\
Opesia width & 0.23 & $0.2-0.26$ & 0.02 & 13 \\
Interzooidal avicularium length & 0.53 & $0.51-0.55$ & 0.03 & 2 \\
Interzooidal avicularia width & 0.28 & $0.25-0.31$ & 0.03 & 3 \\
Avicularian opesia length & - & 0.3 & - & 1 \\
Avicularian opesia width & - & 0.16 & - & 1 \\
\hline
\end{tabular}

Remarks.-Among genera of the family Onychocellidae, our specimen fits better in the genus Smittipora because of the symmetrical and rounded rostrum of its avicularia (Taylor et al., 2018, p. 1702). Although some similarities in the general morphology of the zooid can be found also with species of the genus Floridina Jullien, 1882, this latter genus differs in having acutely triangular rostra, as well as deep opesiular indentations, resulting in a more trifoliate opesia with lateral constrictions (Taylor et al., 2018, p. 1678). Three species of Smittipora have been described from the North American Oligocene and two from the Miocene: S. fusiformis (Canu and Bassler, 1917), $S$. lineata (Canu and Bassler, 1920), S. tenuis (Canu and Bassler, 1920), S. levinseni (Canu and Bassler, 1917), and S. elongata (Canu and Bassler, 1923), respectively. The Oligocene species differ from Smittipora sp. indet. in having exclusively fusiform avicularia; S. levinseni, from the early Miocene to Recent, has smaller zooids and avicularia (Di Martino et al., 2017). Smittipora elongata from the late Miocene lacks proximolateral indentations and a tongue-like medial process on the opesia proximal border. Our specimen also resembles the Cretaceous species Reptolunulites zipfi Taylor and McKinney, 2006 in having a bell-shaped opesia and symmetrical vicarious avicularia, but it differs in having a longer rostrum and a higher ratio between the length of the opesia and the length of the zooid. In the Siamaná Formation, Smittipora sp. indet. was found encrusting coralline algae covering the coral Porites sp., co-occurring with the ascophoran-grade cheilostome Hippopleurifera sp. and an undetermined cheilostome.

Family Steginoporellidae Hincks, 1884 Genus Gymnophorella new genus

Type species.-Gymnophorella hadra n. gen. n. sp., from Arroyo Uitpa, Siamaná Formation, Colombia, early Miocene; by monotypy.

Diagnosis.—As the type species by monotypy.

Etymology.-From the Greek gymno-, referring to the gymnocystal calcification that can form in anascan-grade bryozoans in the frontal wall between the frontal membrane and the free edges of the vertical walls, and -phor meaning carrier, alluding to the presence of a gymnocyst in this Steginoporella-like genus, plus the suffix -ella commonly used in bryozoan names.

Remarks.-Specimens of Gymnophorella $\mathrm{n}$. gen. from the Siamaná Formation are similar to the fossil morphospecies
"Steginoporella" cornuta (Osburn, 1950) recorded by Cheetham et al. (1999) from the Dominican Republic (ca. 7.1 Ma) and Panamanian Caribbean (ca. 3.5 and 1.8 Ma), as well as from the Recent Panamanian Pacific (figured in Cheetham and Jackson, 2000, fig. 2; NMiTA Database, 1996-2016 as aff. "Steginoporella" cornuta and "S." cornuta; STRI Database, 2017 as $S$. cornuta), and to the Brazilian species Steginoporella evelinae Marcus, 1949 (see Winston et al., 2014, p. 147, fig. 5). They all have a narrow band of gymnocyst, more developed proximally, surrounding the cryptocyst and the opesia, a pair of conspicuous tubercles placed at the distal corners of the opesia, and similar shape of the opesia and opesiular indentations. However, in the original description of $S$. cornuta, Osburn (1950, p. 108, pl. 12, figs. 3-6) made no mention of the presence of a gymnocyst, which is effectively absent in the holotype (SBMNH 635758, Fig. 7.1, 7.2), but present in a paratype (SBMNH 636427, Fig. 7.3, 7.4). In addition, Osburn (1950) described B-zooids, also present in "Steginoporella" cornuta from the Pliocene of Panama (Cheetham and Jackson, 2000), but these were not observed or preserved in the material from the Siamaná Formation. On the other hand, the Siamaná specimens differ from $S$. evelinae in having an extended gymnocyst and an evenly granular cryptocyst. The family Steginoporellidae includes to date six genera, of which only Siphonoporella Hincks, 1880 develops a narrow gymnocyst, and has no avicularia or B-zooids (e.g., S. nodosa Hincks, 1880 and $S$. delicatissima [Busk, 1861]). However, this genus differs from Gymnophorella n. gen. in having a lightly calcified skeleton and a very obvious polypide tube (Cook et al., 2018, p. 96). Because Steginoporella sensu stricto lacks a gymnocyst (Harmer, 1926, p. 268; Gordon, 1984, p. 56), we introduce this new genus, and we place it in the family Steginoporellidae owing to its close resemblance with those (morpho-) species of Steginoporella and Siphonoporella discussed above. However, Gymnophorella n. gen. is also similar to some members of Cymuloporidae Winston and Vieira, 2013, Electridae d'Orbigny, 1852 (e.g., Pyripora magna Larwood, 1973), and Calloporidae Norman, 1903 (e.g., Tylopora Lang, 1917) in having oligoserial colonies, and in the morphology of the autozooids showing a well-developed gymnocyst. It differs in having deep opesiular indentations outlining a tongue-like process medially. In addition, Cymuloporidae have colonies exclusively uniserial, and opesia occupying the distal half of the zooid total length; P. magna has a reduced cryptocyst and larger opesiae; and Tylopora spp. has ovicells, avicularia, and sometimes spines on the cryptocyst.

Although the paratype of the Recent Pacific species "Steginoporella cornuta" (SBMNH 636427) exhibits some morphological differences compared to the holotype, and it is likely a new species, its description is not within the objectives of this paper.

\section{Gymnophorella hadra new species Figures 7.5, 8; Table 11}

Holotype.-MUN-STRI-47640. Paratypes: MUN-STRI-4764147644, MUN-STRI-43526. From the early Miocene Siamaná Formation, Arroyo Uitpa, La Guajira, Colombia. 

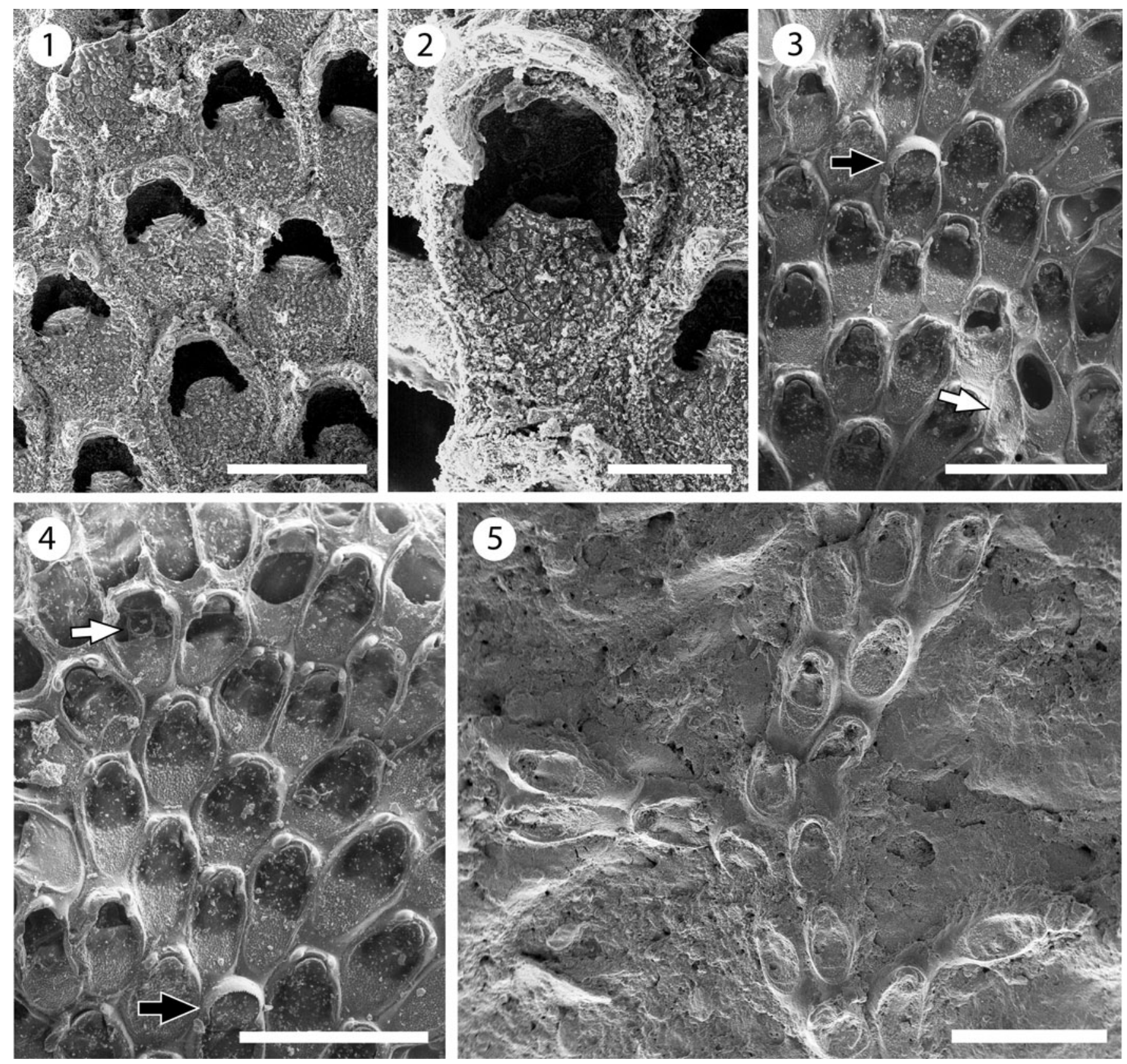

Figure 7. Steginoporella cornuta (Osburn, 1950), Recent, Acapulco, Mexico, Pacific Ocean (holotype SBMNH 635758) (photos courtesy of V. Delnavaz): (1) detail of the autozooids, note the absence of gymnocyst, (2) detail of a B-zooid; Recent, Isla Rancheria, Panama, Pacific Ocean (paratype SBMNH 636427): (3) group of autozooids with reduced gymnocyst in the proximal area, kenozooids (white arrow) and B-zooid (black arrow), (4) autozooid with uncalcified polypide tube (white arrow) and B-zooid (black arrow). Gymnophorella hadra n. gen. n. sp. from the Siamaná Formation, Arroyo Uitpa (paratype MUN-STRI-47643): (5) general view of the uni- and biserial stages, note the extended, proximal gymnocyst. Scale bars are (1) $0.5 \mathrm{~mm} ;(\mathbf{2}) 0.25 \mathrm{~mm} ;(\mathbf{3 - 5}) 1 \mathrm{~mm}$.

Diagnosis. - Colony encrusting, uni- to multiserial. Zooids oval, distinctly separated laterally by a narrow groove. Opesia terminal, trifoliate with deep opesiular indentations outlining a tongue-like process medially; distal opesial margin distinctly raised, lateral margin with two conspicuous tubercles. Cryptocyst granular, unperforated, slightly concave, occupying three-quarters of the zooidal length, surrounded by a raised oval rim that is constricted in the distal opercular region. Gymnocyst relatively extensive, smooth, slightly convex, surrounding the cryptocyst and the opesia, without edges between distal and proximal zooids, more extended proximally in early astogeny. B-zooids seemingly absent. Arrangement uni- and biserial in early astogeny. Kenozooids frequent in multiserial colonies.

Description.-Colony encrusting, unilaminar, uni- to biserial in early astogeny and multiserial in the advanced stages. Bifurcation of the bi- and triserial sections at angles of $\sim 45^{\circ}$. Zooids oval to elliptical, separated laterally by a fine groove (mean $\mathrm{L} / \mathrm{W}=1.68$ ). Opesia terminal, trifoliate, with large opesiular indentations proximally outlining a tongue-shaped process placed medially. Tubercles prominent, blunt, ovate to 


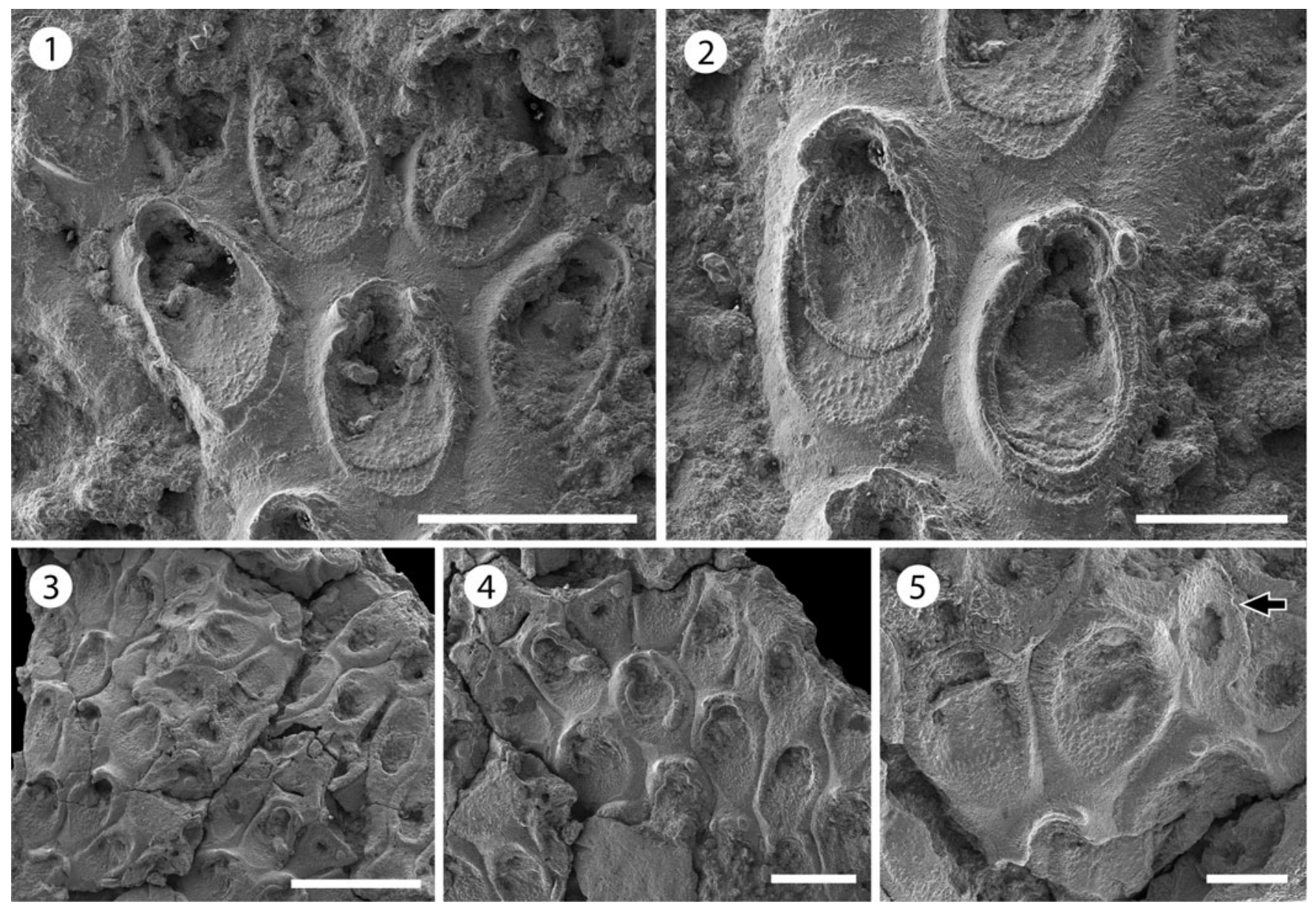

Figure 8. Gymnophorella hadra n. gen. n. sp. from the Siamaná Formation, Arroyo Uitpa (holotype MUN-STRI-47640): (1) detail of the regular autozooids, (2) detail of two autozooids with intramural buds and opesia showing opesiular indentations; (paratype MUN-STRI-47641): $(\mathbf{3}, \mathbf{4})$ general view of the multiserial stage, (5) close-up of autozooids and a kenozooid (arrowed). Scale bars are $(\mathbf{1 , 4}) 0.5 \mathrm{~mm} ;(\mathbf{2}, \mathbf{5}) 0.25 \mathrm{~mm} ;(\mathbf{3}) 1 \mathrm{~mm}$.

elliptic in cross-section, placed laterodistally on each side of the opesia. Cryptocyst extensive and granular, slightly concave, surrounded by a raised mural rim, commonly with intramural buds, occupying three-quarters of the zooid length and being distinctly constricted in the distal opercular region. Gymnocyst smooth, slightly convex, surrounding the cryptocyst and the opesia, extending continually between zooids of the same row except in some bifurcations, more extended in early astogeny and the proximal part of the zooid. Kenozooids frequent in the multiserial stages: triangular, elliptical, or similar in shape to the zooids. Polypide tube and rosette-plates not observed.

Etymology.-From the Greek hadros, meaning well developed, declined in accordance to the gender of the genus, which is feminine, in reference to the well-developed gymnocyst differentiating this genus from other Steginoporellidae.

Remarks. - The absence of B-zooids in the material found in the Siamaná Formation may be a bias related to the limited number of colonies available. For instance, in Steginoporella evelinae, the B-zooids are infrequent and similar in size and shape to the A-zooids (Winston et al., 2014). In the Siamaná Formation, Gymnophorella hadra n. gen. n. sp. was found growing over coral rubble of Porites sp., covered by coralline algae, and sharing the substrate with Antropora guajirensis n. sp., Cribrilaria sp., ?Hippopleurifera sp. 1, and Escharoides sp.

Family Poricellariidae Harmer, 1926

Genus Poricellaria d'Orbigny, 1854

Type species._Poricellaria alata d'Orbigny, 1854 from vicinity of Paris, France, Eocene; by original designation.

Poricellaria sp. indet.

Figure 9.1, 9.2; Table 12

Table 11. Measurements of Gymnophorella hadra $\mathrm{n}$. gen. $\mathrm{n}$. sp. $\mathrm{X}=$ mean; $\mathrm{R}=$ observed range; $\mathrm{SD}=$ standard deviation; $\mathrm{N}=$ number of measurements.

\begin{tabular}{lcccc}
\hline Character & $\mathrm{X}$ & $\mathrm{R}$ & $\mathrm{SD}$ & $\mathrm{N}$ \\
\hline Autozooid length & 0.68 & $0.56-0.86$ & 0.08 & 33 \\
Autozooid width & 0.40 & $0.35-0.46$ & 0.03 & 25 \\
Cryptocyst length & 0.38 & $0.32-0.46$ & 0.05 & 7 \\
Cryptocyst width & 0.29 & $0.24-0.33$ & 0.03 & 14 \\
Opesia length & 0.11 & $0.09-0.12$ & 0.02 & 4 \\
Opesia width & 0.12 & $0.09-0.17$ & 0.03 & 8 \\
Kenozoo length & 0.51 & $0.37-0.66$ & 0.12 & 4 \\
Kenozoo width & 0.34 & $0.21-0.47$ & 0.11 & 4 \\
Opesiule length & 0.08 & $0.07-0.08$ & 0.01 & 3 \\
Opesiule width & 0.04 & $0.03-0.04$ & 0.01 & 2 \\
\hline
\end{tabular}



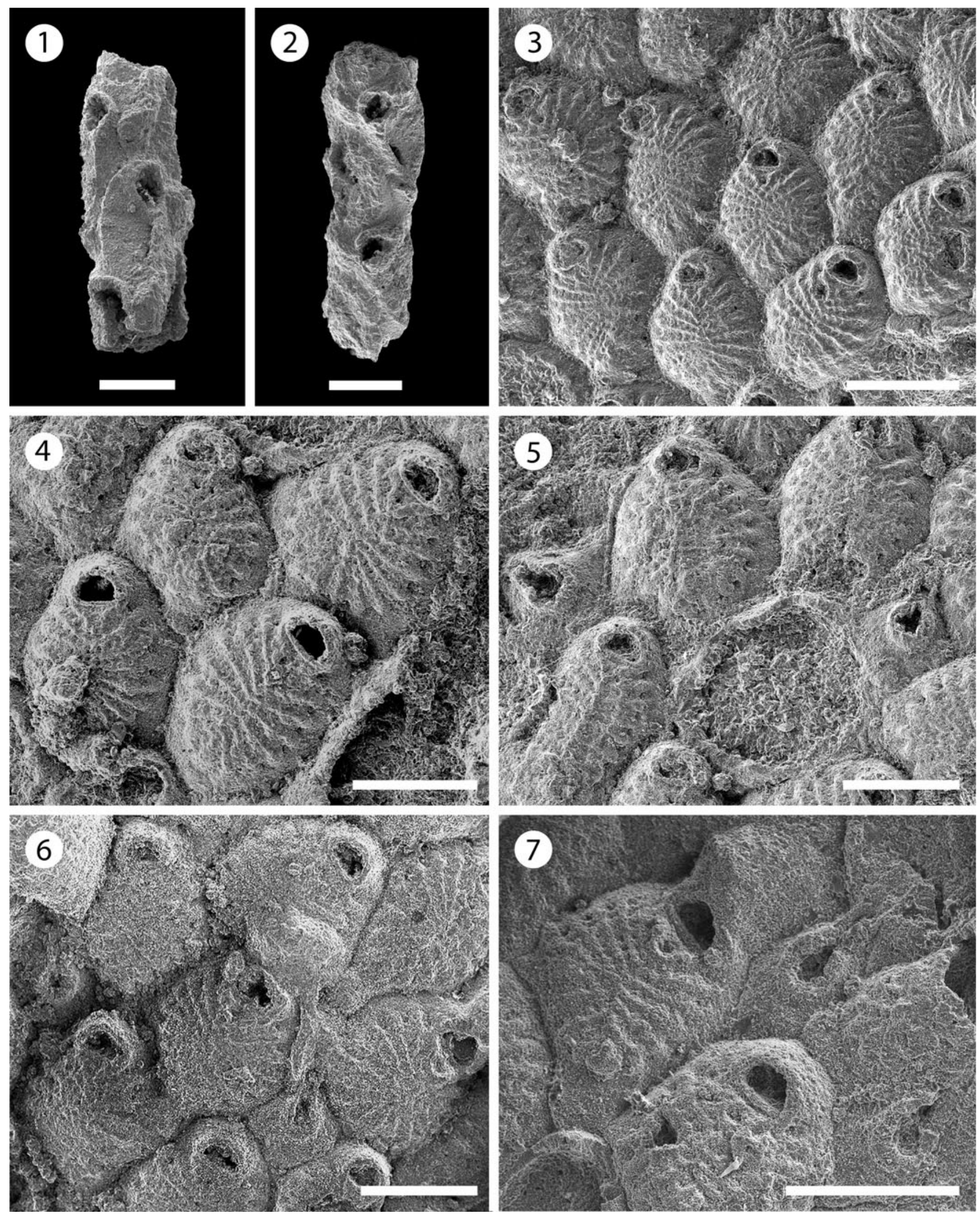

Figure 9. Poricellaria sp. indet. (MUN-STRI-47645): (1, 2) branch fragments showing the oblique orifice and the slit-like opesiule on the cryptocyst. Cribrilaria multicostata n. sp. (holotype MUN-STRI-47650): (3) general view of the autozooids, (4) autozooids showing the orifice shape, spine bases, and suboral lacuna, (5) detail of the avicularium with flared rostrum; (paratype MUN-STRI-47651): (6) fertile zooid with type A ovicell; (paratype MUN-STRI-47652): (7) detail of the avicularium and ovicell. Scale bars are $(\mathbf{1}) 0.15 \mathrm{~mm} ;(\mathbf{2}, \mathbf{4 - 6}) 0.2 \mathrm{~mm} ;(\mathbf{3}, \mathbf{7}) 0.25 \mathrm{~mm}$. 
Table 12. Measurements of Poricellaria sp. indet. $\mathrm{X}=$ mean; $\mathrm{R}=$ observed range; $\mathrm{SD}=$ standard deviation; $\mathrm{N}=$ number of measurements.

\begin{tabular}{lcccr}
\hline Character & $\mathrm{X}$ & $\mathrm{R}$ & $\mathrm{SD}$ & $\mathrm{N}$ \\
\hline Autozooid length & 0.25 & $0.24-0.25$ & 0.01 & 3 \\
Autozooid width & 0.14 & $0.13-0.14$ & 0.01 & 3 \\
Orifice length & 0.06 & $0.05-0.06$ & 0.01 & 2 \\
Orifice width & 0.08 & $0.07-0.08$ & 0.01 & 3 \\
Avicularium length & - & 0.07 & - & 1 \\
Avicularium width & - & 0.04 & - & 1 \\
Opesiule length & 0.07 & $0.06-0.07$ & 0.01 & 2 \\
Branch width & 0.21 & $0.2-0.21$ & 0.01 & 2 \\
\hline
\end{tabular}

Occurrence.—Early Miocene, Siamaná Formation, Arroyo Ekieps, Colombia.

Description.-Colony erect. Branches slender and sub-circular in cross-section. Zooids pyriform (mean $\mathrm{L} / \mathrm{W}=1.80$ ), curved distally, arranged in ?three longitudinal, alternated rows. Orifice terminal, semi-circular, oblique, tilted at an angle of $50-60^{\circ}$ relative to the branch axis, facing frontally and laterally, borders raised. Cryptocyst well developed, oval, smooth, flat, with raised borders, perforated by a single slit-like opesiule, lying adjacent to the raised edge. Gymnocyst well developed, smooth, covering the proximal area. Avicularia adventitious, small, placed on the proximal gymnocyst of each autozooid, rostrum acute and rounded, proximolaterally directed, pivotal bar absent or not preserved. Ovicells not observed.

Remarks.-Only two broken and recrystallized fragments were found in the samples. However, the inclined zooids with the oblique opesia and slit-like opesiule, as well as the avicularia placed on the gymnocyst of each autozooid, are features diagnostic of the genus Poricellaria (Harmer, 1926, p. 313). Nine species of this genus are known worldwide; among these, only Poricellaria vernoni Cheetham, 1963 is known from North America. This species from the Oligocene of Florida differs from Poricellaria sp. indet. in having a finely perforate cryptocyst. Cheetham (1973) found a specimen of Poricellaria in the Caribbean Miocene, which he identified as $P$. aff. ratoniensis; subsequently, Cheetham et al. (1999) reported it as Poricellaria new species 1 (figured in NMiTA Database, 1996-2016) from the Miocene (ca. 15.7-3.9 Ma) of the Dominican Republic. Although the Siamaná material resembles the species found by Cheetham et al. (1999), even in the size of the zooids, the poor preservation and scarcity of specimens preclude any further comparison and the description of a new species. In the Siamaná Formation, Poricellaria sp. indet. was found in the sediment attached to the coral Goniopora hilli, co-occurring with the bryozoan Nellia cf. N. tenella, as is common in other fossil localities and environments (Winston and Cheetham, 1984), as well as Margaretta sp., Ditaxiporina sp., and Mecynoecia sp.

Superfamily Cribrilinoidea Hincks, 1879

Family Cribrilinidae Hincks, 1879

Genus Cribrilaria Canu and Bassler, 1929

Type species.-Eschara radiata Moll, 1803 from the Mediterranean Sea, Recent; by original designation.
Cribrilaria multicostata new species

Figure 9.3-9.7; Table 13

Holotype.-MUN-STRI-47650. Paratypes: MUN-STRI47651-47656. From the early Miocene Siamaná Formation, Arroyo Ekieps, La Guajira, Colombia.

Diagnosis.-Colony encrusting, unilaminar. Zooids oval to rhomboidal. Orifice D-shaped, bearing five spine bases. Lacuna broad, placed in a triangular area between the orifice and the first pair of costae. Frontal shield formed by 13-17 slender costae. Gymnocyst narrow, surrounding the costate shield and the orifice. Interzooidal avicularia with flared rostrum, and rhombic cystid. Ooecium hyperstomial, subglobular, produced by the distal zooid (type A of Bishop and Househam, 1987), smooth, imperforate, and with a median umbo.

Description.-Colony unilaminar, forming extensive and irregular encrustations. Zooids oval to rhomboidal, distinctly separated by deep grooves, longer than wide (mean L/W = 1.17). Orifice transversely D-shaped, bearing five spine bases in non-ovicellate zooids and four in ovicellate zooids, proximal border thick and straight. Frontal shield extensive and convex, formed by 13-17 slender costae; first pair of costae forming a ' $\mathrm{V}$ '-area with a large lacuna visible in some zooids, obliterated by sediment in others; five to six intercostal pores. Gymnocyst narrow. Interzooidal avicularia frequent, large, placed on a rhombic cystid with a well-developed gymnocyst; rostrum flared at the tip with slightly narrow middle portion, oriented distally. Ovicell type A of Bishop and Househam (1987), wider than long; ooecium surface smooth and with a median umbo or keel, not punctate.

Etymology.-From the Latin multus, meaning many, and costa, meaning rib in reference to the greater number of costae that distinguish this species from other Cribrilaria spp. with flared avicularia, plus the suffix -ata, pertaining to.

Remarks.-Two fossil species of Cribrilaria from North America, both from the early Oligocene, are known: Cribrilaria anaticula Canu and Bassler, 1920 and Cribrilaria carolinensis Gabb and Horn, 1862. They resemble Cribrilaria multicostata n. sp. in having five oral spines and large interzooidal avicularia. However, C. multicostata differs from both in having avicularia with a flared rostrum. Nine Recent Cribrilaria morphospecies are described in the literature having avicularia

Table 13. Measurements of Cribrilaria multicostata $\mathrm{n}$. $\mathrm{sp} . \mathrm{X}=$ mean; $\mathrm{R}=$ observed range; $\mathrm{SD}=$ standard deviation; $\mathrm{N}=$ number of measurements.

\begin{tabular}{lclcr}
\hline Character & X & \multicolumn{1}{c}{ R } & SD & N \\
\hline Autozooid length & 0.34 & $0.28-0.44$ & 0.03 & 29 \\
Autozooid width & 0.29 & $0.25-0.4$ & 0.04 & 29 \\
Orifice length & 0.04 & $0.03-0.06$ & 0.01 & 17 \\
Orifice width & 0.07 & $0.06-0.1$ & 0.01 & 12 \\
Avicularium length & 0.29 & $0.25-0.36$ & 0.06 & 3 \\
Avicularium width & 0.15 & $0.11-0.17$ & 0.02 & 9 \\
Ooecium length & 0.14 & $0.12-0.17$ & 0.02 & 5 \\
Ooecium width & 0.16 & $0.15-0.19$ & 0.02 & 6 \\
\hline
\end{tabular}



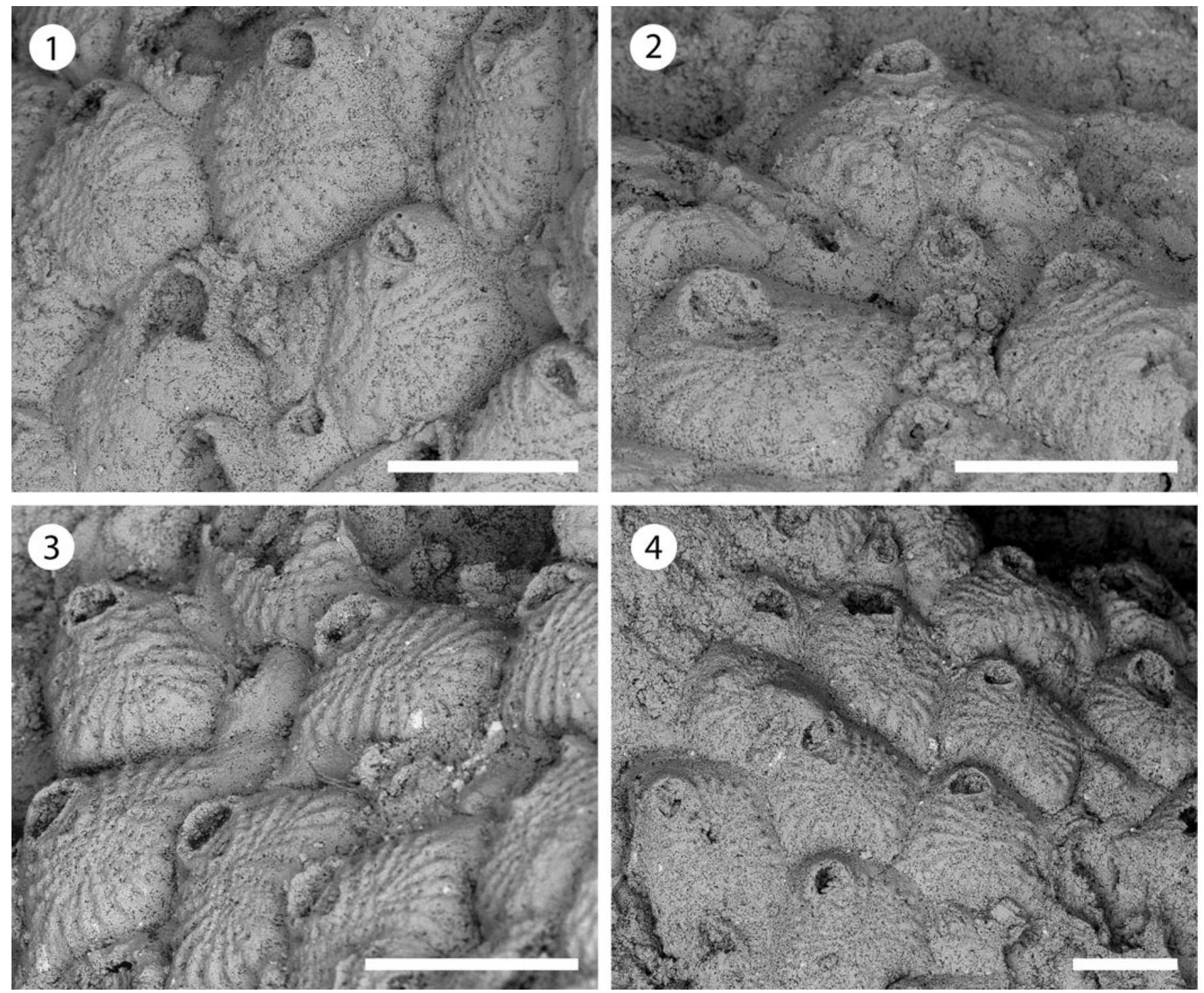

Figure 10. Cribrilaria nixor n. sp. (holotype MUN-STRI-47657): (1-3) autozooids (showing the orifice shape, spine bases, and suboral lacuna) and interzooidal avicularia, (4) fertile zooid with type B ovicell. All specimens are from the Siamaná Formation, Arroyo Ekieps locality. Scale bars are (1-3) 0.3 $\mathrm{mm} ;(\mathbf{4}) 0.25 \mathrm{~mm}$.

with flared mandibles (Harmelin, 2006), seven of them at species level: C. flabellifera (Kirkpatrick, 1888) and C. vaceleti (Harmelin, 2006) from the Indo-Pacific; C. arrecta Bishop and Househam, 1987, C. atlantis (Harmelin, 2006), C. macaronensis (Harmelin, 2006), and C. mikelae (Harmelin, 2006) from the central Atlantic and Mediterranean Sea; and C. smitti (Winston, 2005) from Florida and the Caribbean. Cribrilaria multicostata n. sp. is distinguishable from all of these by having a greater number of costae, up to 17 instead of $5-12$, and five oral spines instead of six or seven (except in C. mikelae, which also bears five). Cribrilaria smitti, the geographically closest congener, differs also in having the first pair of costae more pronounced, leaving a wider space between it and the orifice, where it develops a bifid median umbo. In the Siamaná Formation, Cribrilaria multicostata $\mathrm{n}$. sp. was found encrusting the surface of the coral Acropora panamensis, co-occurring with the bryozoans
Cribrilaria nixor n. sp., Poricella sp., Hippoporina sp., and ? Hippopleurifera sp. 2.

Cribrilaria nixor new species

Figure 10; Table 14

Table 14. Measurements of Cribrilaria nixor $\mathrm{n}$. sp. $\mathrm{X}=$ mean; $\mathrm{R}=$ observed range; $\mathrm{SD}=$ standard deviation; $\mathrm{N}=$ number of measurements.

\begin{tabular}{lcccr}
\hline Character & $\mathrm{X}$ & $\mathrm{R}$ & $\mathrm{SD}$ & $\mathrm{N}$ \\
\hline Autozooid length & 0.45 & $0.36-0.6$ & 0.06 & 12 \\
Autozooid width & 0.37 & $0.32-0.52$ & 0.07 & 7 \\
Orifice length & 0.06 & $0.05-0.07$ & 0.01 & 9 \\
Orifice width & 0.08 & $0.06-0.08$ & 0.01 & 12 \\
Avicularium length & - & 0.34 & - & 1 \\
Avicularium width & 0.23 & $0.17-0.31$ & 0.06 & 4 \\
Ooecium length & - & 0.16 & - & 1 \\
Ooecium width & - & 0.17 & - & 1 \\
\hline
\end{tabular}


Holotype.-MUN-STRI-47657. Paratype: MUN-STRI-47658. From the early Miocene Siamaná Formation, Arroyo Ekieps, La Guajira, Colombia.

Diagnosis.-Colony encrusting. Zooids oval to elliptical. Orifice D-shaped, bearing five spine bases. Lacuna broad and elliptical. Frontal shield formed by 17-22 costae. Gymnocyst narrow. Interzooidal avicularia with slender rostrum, cystid rhombic with extensive gymnocyst. Ovicell hyperstomial, ooecium produced by the distal zooid or kenozooid (type A and B, Bishop and Househam, 1987), smooth, imperforate, and with a median keel.

Description.-Colony encrusting, multiserial, unilaminar. Zooids ovate to elliptical, distinctly separated by shallow grooves (mean $\mathrm{L} / \mathrm{W}=1.21$ ). Orifice semicircular, wider than long; proximal border straight, formed by a thin bar. Five oral spine bases in non-ovicellate zooids and four in ovicellate zooids. Frontal shield extensive, slightly convex to flat, formed by 17-22 slender costae, tapering at the distal end, and fusing in the middle line. Costae separated by two to five circular intercostal pores. Suboral lacuna broad, elliptic, flanked by the first pair of costae forming a ' $V$ '. Gymnocyst very narrow. Interzooidal avicularia frequent, rostrum long and slender, cystid rhombic with a well-developed gymnocyst, oriented distally, sometimes lying on the frontal shield of the distal zooid, opesia oval. Ooecium type A and B (Bishop and Househam, 1987), longer than wide, surface smooth, not punctate, and with a median keel. Kenozooids present.

Etymology.-From the Latin nixor, meaning leaning against, and used as a name in apposition, in reference to the interzooidal avicularia that lean against the frontal shield of the distal autozooids.

Remarks.-Although a single colony is available for this species, several features (e.g., the number of costae, length of the zooids, type of ovicell budding from a kenozooid [type B], wider avicularian opesia, and long and slender rostrum) allow Cribrilaria nixor n. sp. to be distinguished from Cribrilaria multicostata $\mathrm{n}$. sp. occurring in the same deposits. Cribrilaria nixor n. sp. differs from Cribrilaria anaticula and Cribrilaria carolinensis, both recorded in the early Oligocene of North America (Canu and Bassler, 1920, p. 297), in having a greater number of costae (17-22 vs. 10-12) and in the shape of the avicularian rostrum, which is duck beak-shaped in C. anaticula, or thin and channeled in C. carolinensis. In the Siamaná Formation, Cribrilaria nixor n. sp. was found encrusting the surface of the coral Acropora panamensis, co-occurring with the bryozoans C. multicostata n. sp., Poricella sp., Hippoporina sp., and ?Hippopleurifera sp. 2.

Genus Figularia Jullien, 1886

Type species.-Lepralia figularis Johnston, 1847 from Cornwall, United Kingdom, Recent; by original designation.

Figularia bragai new species

Figure 11.1-11.5; Table 15
Holotype.-MUN-STRI-47647. Paratypes: MUN-STRI-47648, MUN-STRI-47649. From the early Miocene Siamaná Formation, Arroyo Ekieps, La Guajira, Colombia.

Diagnosis. - Colony encrusting. Gymnocyst smooth, developed laterally and proximally. Frontal shield formed by 19-24 costae with a pelma located near the tip close to the median, fusion line of the costate shield. Orifice semi-circular with a centered, suboral pore. Putative, vicarious avicularia infrequent. Ooecium ovoidal with two drop-shaped or slit-like fenestrae, and a longitudinal suture medially.

Description.-Colony encrusting, multiserial, uni- to multilaminar. Zooids large (mean $\mathrm{L} / \mathrm{W}=1.68$ ), rhomboidal to elliptical, flat to slightly convex, distinctly separated by fine and shallow furrows. Gymnocyst smooth, slightly convex, developed laterally and proximally, occupying one-quarter of the frontal length of the zooid. Frontal shield oval, flat to slightly convex, a little raised above the level of the gymnocyst, formed by 19-24 adjacent costae, fused in the median line. Costae broad, bar-shaped in the central and distal area, tapering proximally, apparently separated by one to three slit-like intercostal lacunae; each costa bears a circular pelma placed close to the fusion line of the costae. Orifice terminal, wide, semi-circular, straight proximally, with a suboral, small, centered pore. Putative interzooidal avicularia infrequent, narrow, almost half of the zooid width, but similar in length. Ovicell hyperstomial, ovoidal; ectooecium smooth, with a longitudinal suture in the median line; two drop-shaped or slit-like fenestrae, oriented transversally, exposing a smooth endooecium. Ancestrula unknown. Kenozooids absent.

Etymology.-Named after Professor Juan Carlos Braga, paleontologist (Departamento de Estratigrafía y Paleontología, Universidad de Granada, Spain), in recognition of his support in the study of recent and fossil bryozoans from Colombia.

Remarks.-Figularia bragai n. sp. resembles the Miocene species from Indonesia ?Filaguria kalimantanensis Di Martino and Taylor, 2015 in the size of zooids, number of costae, position of the pelma, and the morphology of the ooecium. However, the latter species has putative vicarious avicularia similar to autozooids, and two lateral oral spine bases, which are diagnostic of the genus Filaguria Moyano, 1991 and absent in the Colombian material. However, in Figularia bragai n. sp. we observed a single polymorph, which can be interpreted either as a putative vicarious avicularium with spoon-shaped rostrum and complete cross-bar, or as a malformed autozooid with broken costate shield, constricted between two neighboring zooids with reversed polarity.

Vicarious avicularia with a spoon-shaped rostrum have been described for several species of Figularia: the Recent species $F$. fissa (Hincks, 1880) and F. fissurata Canu and Bassler, 1929, and Miocene species F. rhodanica Li, 1990 (see Li, 1990, pl. 2, fig. 11), but they all differ from the new species in the number of costae, number and size of pelmata, and/or characters of the ooecium (Rosso et al., 2020). Figularia bragai n. sp. also differs from the Recent species recorded from the Gulf 

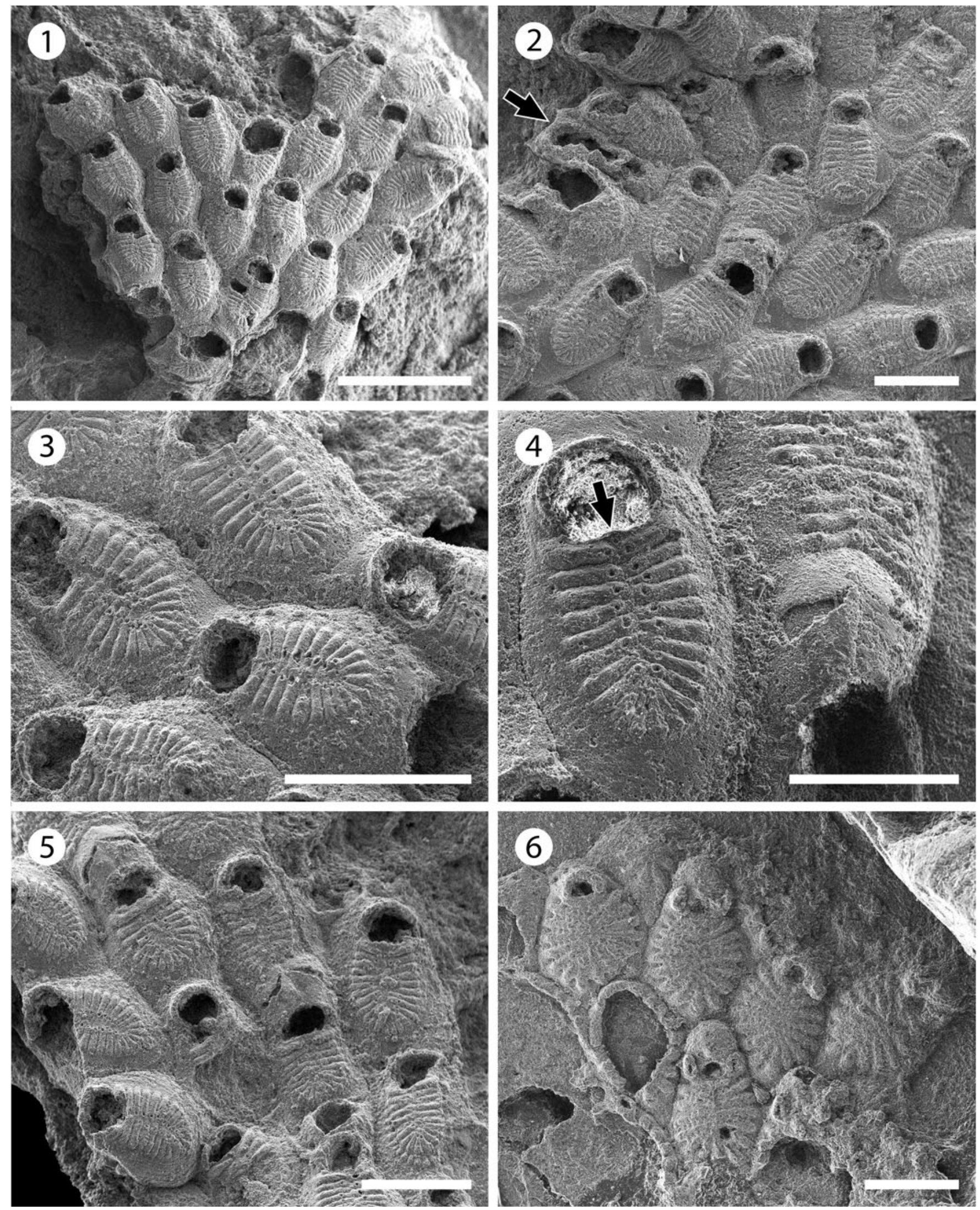

Figure 11. Figularia bragai $n$. sp. (MUN-STRI-47647): (1) general view of the colony, (2) autozooids and interzooidal avicularia (arrowed), (3) close-up of autozooids showing the frontal shield (costae and pelma) and the smooth gymnocyst, (4) close-up of a zooid showing the shape of the orifice, the suboral pore (arrowed), and an ovicell, (5) group of ovicellate and non-ovicellate zooids. Glabrilaria sp. indet. (MUN-STRI-47646): (6) general view of the colony. Scale bars are (1) 1 mm; $(\mathbf{2}, \mathbf{3}, \mathbf{5}) 0.5 \mathrm{~mm} ; \mathbf{( 4 )} 0.3 \mathrm{~mm} ;(\mathbf{6}) 0.25 \mathrm{~mm}$. 
Table 15. Measurements of Figularia bragai $\mathrm{n}$. sp. $\mathrm{X}=$ mean; R= observed range; $\mathrm{SD}=$ standard deviation; $\mathrm{N}=$ number of measurements.

\begin{tabular}{lcccr}
\hline Character & $\mathrm{X}$ & $\mathrm{R}$ & $\mathrm{SD}$ & $\mathrm{N}$ \\
\hline Autozooid length & 0.72 & $0.59-0.88$ & 0.10 & 10 \\
Autozooid width & 0.43 & $0.34-0.52$ & 0.05 & 10 \\
Orifice length & 0.14 & $0.11-0.17$ & 0.02 & 9 \\
Orifice width & 0.20 & $0.17-0.23$ & 0.02 & 9 \\
Cryptocyst length & 0.39 & $0.29-0.46$ & 0.06 & 10 \\
Cryptocyst width & 0.30 & $0.25-0.35$ & 0.03 & 11 \\
Pelma diameter & 0.01 & 0.01 & 0 & 2 \\
Avicularium length & - & 0.72 & - & 1 \\
Avicularium width & - & 0.2 & - & 1 \\
Ooecium length & 0.21 & $0.2-0.22$ & 0.01 & 3 \\
Ooecium width & 0.35 & $0.34-0.35$ & 0.01 & 3 \\
Fenestra length & 0.16 & $0.12-0.18$ & 0.03 & 3 \\
Fenestra width & 0.03 & $0.02-0.04$ & 0.01 & 2 \\
\hline
\end{tabular}

of Mexico and listed as doubtful in Rosso et al. (2020, table 4), ?Figularia ampla Canu and Bassler, 1928, and Figularia contraria Lagaaij, 1963, in the number of costae and size of the zooids and opesiae; the former species has six pairs of costae, and larger zooids ( $1.5 \mathrm{~mm}$ long, $1.0 \mathrm{~mm}$ wide); while the latter species has $8-11$, more commonly nine, costae and a distinctly smaller opesia in ovicellate zooids. The absence of a pelma and proximal and lateral gymnocyst in the species described and figured by Canu and Bassler (1920, p. 316, pl. 43, fig. 9) as ?Figularia crassicostulata (Canu and Bassler, 1920) from the late Eocene of North America suggests that this specimen does not belong to the genus Figularia (Rosso et al., 2020). In the Siamaná Formation, F. bragai n. sp. was found encrusting the underside of the coral Colpophyllia willoughbiensis as well as the lateral surface of Porites baracoaensis Vaughan, 1919 and Acropora sp., sharing the substrate with an undetermined Cribrilinidae, ?Hippopleurifera sp. 2, Gemelliporidra sp., and ?Hippomenella sp.

\section{Genus Glabrilaria Bishop and Househam, 1987}

Type species.-Puellina pedunculata Gautier, 1956 from Le Grand Congloué Island, Archipelago of Riou, France, Recent; by original designation.

Glabrilaria sp. indet.

Figure 11.6, 12; Table 15

Occurrence.-Early Miocene, Arroyo Ekieps, Siamaná Formation, Colombia.

Description.-Colony encrusting, unilaminar. Zooids oval and small (mean $\mathrm{L} / \mathrm{W}=1.36$ ). Orifice terminal, transversely D-shaped, bearing six to seven spine bases in non-ovicellate zooids. Gymnocyst very narrow, developed proximally and laterally. Frontal shield formed by $13-15$ costal ridges, fused in the middle line without forming a median suture or umbo. Between the costae, five or six lacunae are visible. A pair of small adventitious avicularia with a triangular rostrum located on each side of the orifice of ovicellate zooids, oriented distally; rostrum small, raised at its distal end. Ooecium globular, produced by the distal kenozooid, apparently with a proximo-median umbo or keel. Kenozooids present. Ancestrula not preserved.
Remarks.-Ten species of Glabrilaria have been recognized to date. Among them, the Mediterranean Glabrilaria pedunculata (Gautier, 1956) has the oldest record, ranging from the late Miocene (Pouyet, 2000) to the Recent. In the American continent, two Recent species, Glabrilaria hirsuta Rosso in Rosso et al., 2018 and Glabrilaria polita Rosso in Rosso et al., 2018, have been recorded in the deep waters of the central West Atlantic, associated with coral fragments (Rosso et al., 2018). The Siamaná species differs from G. pedunculata and G. polita in having 6-7 (and not five) oral spine bases in non-ovicellate zooids. Although G. hirsuta also has seven oral spines, it differs from the present material in having on average a greater number of costae (13-15 vs. 1418) and a larger ooecium. However, the Siamaná colony is too small and poorly preserved to observe the characteristic spiny ornamentation, the transversal processes of the ooecia, and/or the clustering of kenozooids typical of G. hirsuta (Rosso et al., 2018). Owing to these reasons, we prefer to keep this species in open nomenclature. In the Siamaná Formation Glabrilaria sp. indet. was found encrusting a mollusk shell, sharing the substrate with Atoichos magnus n. gen. n. sp. and a poorly preserved cyclostome.

\section{Discussion}

The majority of the bryozoan species described here are cheilostomes (87\%), among which the family Cribrilinidae, with four species, is the most diverse, as already observed in shallow- and deep-water ecosystems with carbonate substrates, both fossil and Recent (Winston, 2016). The family Onychocellidae is represented by two species, while the remaining nine families are represented by only one species each. Only two species, both left in open nomenclature, are cyclostomes $(13 \%)$.

Seven of the species (47\%) found in the Siamaná Formation are new, including three cribrilinids (Cribrilaria multicostata n. sp., Cribrilaria nixor n. sp., and Figularia bragai n. sp.), an antroporid (Antropora guajirensis $\mathrm{n}$. sp.), a microporid (Calpensia caribensis n. sp.), an onychocellid (Atoichos magnus n. gen. n. sp.), and a steginoporellid (Gymnophorella hadra n. gen. n. sp.).

The remaining species (53\%) are left in open nomenclature owing to their poor preservation, the absence of diagnostic features as gonozooids or ovicells, or the scarcity of available material. Species with erect colonies were commonly found only as small branch fragments, while for those with encrusting colonies only a few autozooids were recorded.

In the assemblage, $73 \%$ of the species have encrusting colonies, 20\% have erect articulated colonies, and the remaining $7 \%$ have erected rigid colonies. The dominance of encrusting forms is a typical pattern in coral reef environments, favored by the availability of hard substrates (Winston, 1986; Hamdane and Moissette, 2002; Cuffey, 2011). By contrast, taxa with freeliving colonies, which in the Caribbean region are diverse and abundant from the middle Miocene (from ca. $15 \mathrm{Ma}$ ) to the Recent (Cheetham and Jackson, 2000; Flórez et al., 2007; O'Dea, 2009) are absent in the material studied here. This is probably a sampling/environmental bias with the collection focused on the reef framework, whereas free-living bryozoans 

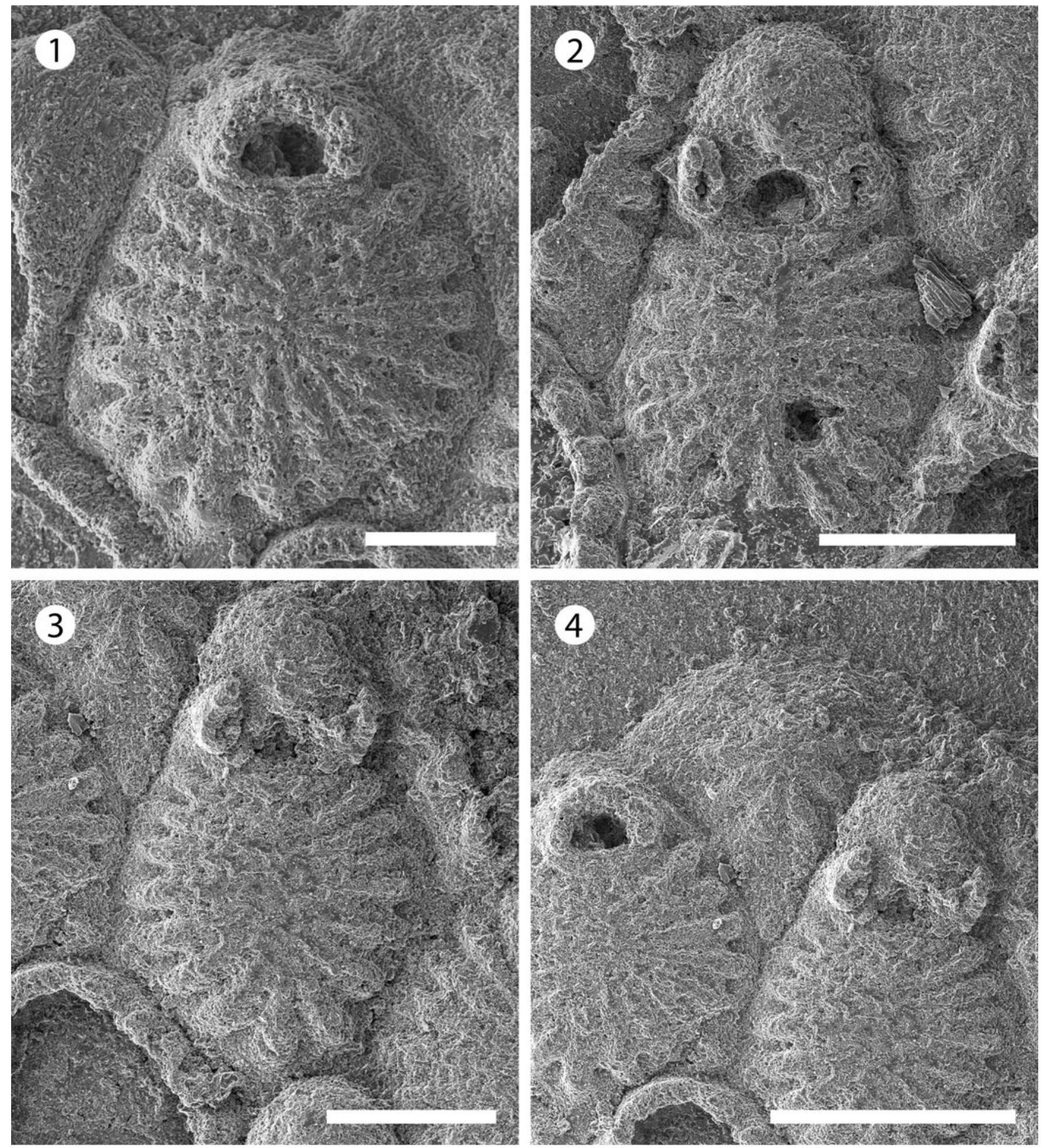

Figure 12. Glabrilaria sp. indet. (MUN-STRI-47646): (1) close-up of a non-ovicellate autozooid, showing the orifice shape, oral spine bases, and pore chamber windows, $(\mathbf{2}, \mathbf{3})$ close-up of ovicellate zooids with paired latero-oral avicularia, (4) detail of a kenozooid. All specimens are from the Siamaná Formation, Arroyo Ekieps locality. Scale bars are (1) $0.1 \mathrm{~mm} ;(\mathbf{2}, \mathbf{3}) 0.15 \mathrm{~mm} ; \mathbf{( 4 )} 0.25 \mathrm{~mm}$.

are adapted to live on the soft bottoms surrounding the reefs, as well as at greater depths in muddy environments (O’Dea, 2009).

In the Siamaná Formation, encrusting bryozoans were found on the bases and undersurfaces of scleractinian corals (e.g., Alveopora tampae, Acropora panamensis, Colpophyllia willoughbiensis, Porites baracoaensis, Acropora sp., and Porites sp.), as well as on coralline algae that covered the coral rubble, and on mollusk shells. On the other hand, the erect articulated species were found in the sediment attached to the bases and inter-branch spaces of corals such as Goniopora 
Table 16. Measurements of Glabrilaria sp. indet. $\mathrm{X}=$ mean; $\mathrm{R}=$ observed range; $\mathrm{SD}=$ standard deviation; $\mathrm{N}=$ number of measurements.

\begin{tabular}{lcccr}
\hline Character & $\mathrm{X}$ & $\mathrm{R}$ & $\mathrm{SD}$ & $\mathrm{N}$ \\
\hline Autozooid length & 0.38 & $0.34-0.41$ & 0.03 & 4 \\
Autozooid width & 0.28 & $0.25-0.33$ & 0.04 & 4 \\
Orifice length & 0.04 & $0.04-0.05$ & 0.01 & 3 \\
Orifice width & 0.06 & $0.05-0.07$ & 0.01 & 3 \\
Avicularium rostrum length & 0.07 & $0.06-0.07$ & 0.01 & 4 \\
Avicularium rostrum width & 0.04 & $0.04-0.05$ & 0.01 & 4 \\
Ooecium length & 0.11 & 0.11 & 0 & 2 \\
Ooecium width & 0.15 & $0.14-0.15$ & 0 & 2 \\
\hline
\end{tabular}

hilli, A. tampae, and A. panamensis. Erect articulated bryozoans are also common in coral reefs (Winston, 1986; Cuffey, 2011), both modern and fossil, commonly deeper inside the protected cavities (Hamdane and Moissette, 2002).

Most species were found at the locality Arroyo Ekieps (80\%), whereas at Arroyo Uitpa only Antropora guajirensis n. sp., Smittipora sp. indet., and Gymnophorella hadra n. gen. n. sp. were recorded (20\%). In both cases, the species were exclusive of the locality. The Arroyo Uitpa paleoenvironment was characterized by patch reefs developed in a shallow lagoon close to the shore-line, while Arroyo Ekieps was a barrier reef system (Flórez et al., 2019a, b; and unpublished data), which offered a wide variety of microhabitats enhanced by the structural complexity of the reef framework. This suggests an increase of bryozoan diversity with higher reef complexity, as has been observed in modern reefs off Andros and Eleuthera in the Bahamas (Cuffey and Fonda, 1977).

In the Siamaná Formation, cryptic encrusting bryozoan colonies contribute to the fill of cavities reinforcing the reef framework, and articulated colonies contribute to production of sediment, in accordance with the role of bryozoans in fossil and modern coral reef building in tropical shallow waters (Cuffey, 1977, 2011; Insalaco, 1998; Taylor and James, 2013; Ramalho et al., 2018).

\section{Acknowledgments}

Financial support for this study was provided by Colciencias (Colombia) across the scholarship Doctorados en el Exterior 728. We are grateful for the financial support of the expeditions to the project 727756933195 (Colciencias), Ecopetrol S.A., STRI, University of Zurich, Universidad del Norte, NSF (Grant EAR 0957679), National Geographic Society, Anders Foundation, 1923 Fund, and G.D. and J. Walston Johnson. EDM has received funding from the European Research Council (ERC) under the European Union's Horizon 2020 research and innovation programme (grant agreement No 724324 to L.H. Liow). Special thanks to J.C. Braga and P.D. Taylor for the support and helpful comments on the manuscript, to P. Zapata for the collection of coral samples during the expedition 2011, and C. Jaramillo for encouraging the study. Thanks to V. Delnavaz (SBMNH) for SEM pictures of type material; I. Sánchez for assistance with SEM pictures; J. Souto, C.M. López-Fé, and L. Vieira for their taxonomic advice; R. Cuffey, P. Bock, and J. Cancino for sharing literature; ARES team and Wayúu community for help in field and logistics. B. Berning and K. Zágoršek provided useful comments that greatly improved the original submitted manuscript.

\section{References}

Almeida, A.C.S., Souza, F.B.C., Menegola, C.M.S., and Vieira, L.M., 2017 Diversity of marine bryozoans inhabiting demosponges in northeastern Brazil: Zootaxa, v. 4290, p. 281-323.

Audouin, J.V., 1826, Explication sommaire des planches de polypes de l'Egypte et de la Syrie, publiées par Jules-Cesar Savigny, in Audouin, J.V., ed., Description de L'Egypte, ou recueil des observations et des recherches qui ont été faites en Egypte pendant l'expédition de l'armée française. Histoire Naturelle 1: Paris, Imprimerie Impériale, 339 p.

Bassler, R.S., 1953, Bryozoa Part G. in Moore, R.C., ed., Treatise on Invertebrate Paleontology: Boulder, Colorado and Lawrence, Kansas, Geological Society of America and University of Kansas Press, 253 p.

Bishop, J.D.D., and Househam, B.C., 1987, Puellina (Bryozoa; Cheilostomatida; Cribrilinidae) from British and adjacent waters: Bulletin of the British Museum (Natural History): Zoology, v. 53, p. 1-63.

Bloch, J.I., Woodruff, E.D., Wood, A.R., Rincon, A.F., Harrington, A.R., Morgan, G.S., Foster, D.A., Montes, C., Jaramillo, C.A., Jud, N.A., Jones, D.S., and MacFadden, B.J., 2016, First North American fossil monkey and early Miocene tropical biotic interchange: Nature, v. 533, p. 243-246.

Brown, A.P., and Pilsbry, H.A., 1913, Two collections of Pleistocene fossils from the Isthmus of Panama: Proceedings of the Academy of Natural Sciences of Philadelphia, v. 65, p. 493-500.

Buge, E., 1957, Les Bryozoaires du Néogène de l'Ouest de la France et leur signification stratigraphique et paléobiologique: Mémoires du Muséum national d'Histoire naturelle, v. 6, p. 1-436.

Buge, E., 1973, Les Bryozoaires Miocènes du Nord-ouest de l'Allemagne: Paläontologische Zeitschrift, v. 47, p. 32-53.

Busk, G., 1852a, An account of the Polyzoa, and sertularian zoophytes, collected in the Voyage of the Rattlesnake, on the coasts of Australia and the Louisiade Archipelago, in MacGillivray, J., ed., Narrative of the Voyage of the H.M.S. Rattlesnake 1: London, T. and W. Boone, p. 343-402.

Busk, G., 1852b, Catalogue of marine Polyzoa in the collection of the British Museum. I. Cheilostomata: London, Trustees of the British Museum (Natural History), Taylor and Francis, p. 1-54.

Busk, G., 1854, Catalogue of marine Polyzoa in the collection of the British Museum, II. Cheilostomata (part): London, Trustees of the British Museum (Natural History), Taylor and Francis, p. 55-120.

Busk, G., 1859, A monograph of the fossil Polyzoa of the Crag: London, The Palaeontographical Society, $136 \mathrm{p}$.

Busk, G., 1861, Zoophytology. Descriptions of new and imperfectly known Polyzoa. No. 1: Quarterly Journal of Microscopical Science, New Series, v. 1, p. $153-156$.

Buzas, M.A., Collins, L.S., and Culver, S.J., 2002, Latitudinal difference in biodiversity caused by higher tropical rate of increase: Proceedings of the National Academy of Sciences, v. 99, p. 7841-7843.

Canu, F., 1900, Révision des Bryozoaires du Crétacé figurés par d’Orbigny. II, Cheilostomata: Bulletin de la Société Géologique de France, v. 3, p. 334-463.

Canu, F., 1918, Les ovicelles des Bryozoaires cyclostomes. Étude sur quelques familles nouvelles et anciennes: Bulletin de la Societé Géologique de France, v. 4, p. 324-335.

Canu, F., and Bassler, R.S., 1917, A synopsis of American Early Tertiary Cheilostome Bryozoa: United States National Museum Bulletin, v. 96, p. 1-87.

Canu, F., and Bassler, R.S., 1919, Fossil Bryozoa from the West Indies: Publications of the Carnegie Institution, v. 291, p. 75-102.

Canu, F., and Bassler, R.S., 1920, North American early Tertiary Bryozoa: United States National Museum Bulletin, v. 106, p. 1-879.

Canu, F., and Bassler, R.S., 1923, North American later Tertiary and Quaternary Bryozoa: United States National Museum Bulletin, v. 125, p. 1-302.

Canu, F., and Bassler, R.S., 1927, Classification of the cheilostomatous Bryozoa: Proceedings of the U.S. National Museum, v. 69, p. 1-42.

Canu, F., and Bassler, R.S., 1928, Fossil and recent Bryozoa of the Gulf of Mexico region: Proceedings of the U.S. National Museum, v. 72, p. 1-199.

Canu, F., and Bassler, R.S., 1930, Bryozoaires marins de Tunisie: Annales de la Station Océanographique de Salambô, v. 5, p. 1-91.

Cheetham, A.H., 1954, A new Early Cretaceous bryozoan from Texas: Journal of Paleontology, v. 28, p. 177-184.

Cheetham, A.H., 1963, Late Eocene zoogeography of the eastern Gulf Coast region: Memoirs of the Geological Society of America, v. 91, p. 1-113.

Cheetham, A.H., 1966, Cheilostomatous Polyzoa from the Upper Bracklesham Beds (Eocene) of Sussex: Bulletin of the British Museum Natural History, Geology, v. 13, p. 1-115. 
Cheetham, A.H., 1968, Evolution of zooecial asymmetry and origin of poricellariid cheilostomes: Atti della Società Italiana di Scienze Naturali e del Museo Civico di Storia Naturale, Milano, v. 108, p. 185-194.

Cheetham, A.H., 1973, Study of Cheilostome polymorphism using Principal Components Analysis, in Larwood, G.P., ed., Living and Fossil Bryozoa: London, Academic Press, p. 385-409.

Cheetham, A.H., and Jackson, J.B.C., 1996, Speciation, extinction, and the decline of arborescent growth in Neogene and Quaternary cheilostome bryozoa of tropical America, in Jackson, J.B.C., Budd, A.F., and Coates, A.G., eds., Evolution and Environment in Tropical America: Chicago, University of Chicago Press, p. 205-233.

Cheetham, A.H., and Jackson, J.B.C., 2000, Neogene history of Cheilostome Bryozoa in tropical America, in Herrera-Cubilla, A., and Jackson, J.B.C., eds., Proceedings of the 11th International Bryozoology Association Conference: Balboa, Panama, Smithsonian Tropical Research Institute, p. 1-16.

Cheetham, A.H., Sanner, J., Taylor, P.D., and Ostrovsky, A.N., 2006, Morphological differentiation of avicularia and the proliferation of species in midCretaceous Wilbertopora Cheetham, 1954 (Bryozoa: Cheilostomata) Journal of Paleontology, v. 80, p. 49-71.

Cheetham, A.H., Sanner, J., and Jackson, J.B.C., 2007, Metrarabdotos and related genera (Bryozoa: Cheilostomata) in the late Paleogene and Neogene of tropical America: Journal of Paleontology, v. 81, p. 1-91.

Choi, D.R., 1984, Ecological succession of reef cavity-dwellers (coelobites) in coral rubble: Bulletin of Marine Science, v. 35, p. 72-79.

Clarke, A., and Lidgard, S., 2000, Spatial patterns of diversity in the sea: Bryozoan species richness in the North Atlantic: Journal of Animal Ecology, v. 69 , p. $799-814$.

Cook, P.L., 1968, Polyzoa from West Africa, the Malacostega, Pt. I: Bulletin of the British Museum (Natural History), Zoology, v. 16, p. 115-160.

Cook, P.L., and Bock, P.E., 2001, Calescharidae, a new family for the Tertiary to Recent genera Caleschara MacGillivray and Tretosina Canu and Bassler (Bryozoa: Cheilostomata): Invertebrate Taxonomy, v. 15, p. 527-550.

Cook, P.L., Bock, P.E., Gordon, D.P., and Weaver, H.J., 2018, Australian Bryozoa Volume 2. Taxonomy of Australian Families: Melbourne, CSIRO Publishing, $320 \mathrm{p}$.

Cuffey, R.J., 1977, Bryozoan contributions to reefs and bioherms through time: Studies in Geology, v. 4, p. 181-194.

Cuffey, R.J., 2011, Bryozoa, in Hopley, D., ed., Encyclopedia of Modern Coral Reefs. Part 2. Structure, Form and Process: Dordrecht, Springer, p. 172-177.

Cuffey, R.J., and Fonda, S.S., 1977, Cryptic bryozoan species assemblages in modern coral reefs off Andros and Eleuthera, Bahamas: Proceedings of the 3rd International Coral Reef Symposium, v. 1, p. 81-86.

Cuffey, R.J., and Kissling, D.L., 1973, Ecologic roles and paleoecologic implications of bryozoans on modern coral reefs in the Florida Keys: Geological Society of America, Abstracts with Programs, v. 5, p. 152-153.

Di Martino, E., and Taylor, P.D., 2014, Miocene Bryozoa from East Kalimantan, Indonesia. Part 1: Cyclostomata and 'Anascan' Cheilostomata: Scripta Geologica, v. 146, p. 17-126.

Di Martino, E., and Taylor, P.D., 2015, Miocene Bryozoa from East Kalimantan, Indonesia. Part II: 'Ascophoran' Cheilostomata: Scripta Geologica, v. 148, p. $1-142$.

Di Martino, E., and Taylor, P.D., 2017, Some Miocene cheilostome bryozoan genera of Michel Vigneaux-systematic revision and scanning electron microscopic study: Geodiversitas, v. 39, p. 783-796.

Di Martino, E., Taylor, P.D., and Portell, R.W., 2017, Bryozoans from the lower Miocene Chipola Formation, Calhoun County, Florida, USA: Bulletin of the Florida Museum of Natural History, v. 53, p. 97-200.

Di Martino, E., Jackson, J.B.C., Taylor, P.D., and Johnson, K.G., 2018, Differences in extinction rates drove modern biogeographic patterns of tropical marine biodiversity: Science Advances, v. 4, eaaq1508, doi:10.1126/sciadv.aaq1508.

Di Martino, E., Taylor, P.D., and Portell, R.W., 2019, Anomia-associated bryozoans from the upper Pliocene (Piacenzian) lower Tamiami Formation of Florida, USA: Palaeontologia Electronica, 22.1.11.A, p. 1-65, doi:10.26879/920.

d'Orbigny, A., 1851-1854, Paléontologie française. Description des Mollusques et Rayonées fossils. Terrains crétacés. Tome 5 Bryozoaires: Paris, Victor Masson, $1192 \mathrm{p}$

Duque-Caro, H., 1974, Los foraminíferos planctónicos y el Terciario de Colombia: Revista Española de Micropaleontología, v. 7, p. 403-427.

Duvergier, J., 1920, Note sur les Bryozoaires du Néogène de l'Aquitaine: Actes de la Société Linnéenne de Bordeaux, v. 72, p. 145-182.

Ellis, J., and Solander, D., 1786, The Natural History of Many Curious and Uncommon Zoophytes Collected from Various Parts of the Globe: London, Benjamin White and Son; and Peter Elmsly, 206 p.

Esper, E.J.C., 1797, Forsetzungen der Pflanzenthiere in Abbildungen nach der Natur mit Farben erleuchtet hebst Beschreibungen: Nürnberg, Raspischen Buchhandlung, v. 1, 230 p.

Flórez, P., Montoya-Cadavid, E., Reyes-Forero, J., and Santodomingo, N., 2007, Briozoos Cheilostomados del Caribe colombiano: Boletín de Investigaciones Marinas y Costeras, Invemar, v. 36, p. 229-250.
Flórez, P., Zapata-Ramírez, P., and Klaus, J.S., 2019a, Early Miocene shallowwater corals from La Guajira, Colombia: Part I, Acroporidae-Montastraeidae: Journal of Paleontology, v. 93, p. 1-24.

Flórez, P., Zapata-Ramírez, P., and Klaus, J.S., 2019b, Early Miocene shallowwater corals from La Guajira, Colombia: Part II, Mussidae-Siderastreidae and Milleporidae: Journal of Paleontology, v. 93, p. 416-436.

Gabb, W.M., and Horn, G.H., 1862, The fossil Polyzoa of the Secondary and Tertiary Formations of North America: Journal of the Academy of Natural Sciences of Philadelphia, v. 5, p. 111-179.

Gautier, Y.V., 1956, Résultats scientifiques des campagnes de la "Calypso". Fascicule II. Études sur l'îlot du Grand Congloué (Archipel de Riou, près Marseille). 5. Bryozoaires: Annales de l'Institut océanographique, v. 32, p. $189-225$

Geister, J., 1992, Modern reef development and Cenozoic evolution of an oceanic island/reef complex: Isla de Providencia (Western Caribbean Sea, Colombia): Facies, v. 27, p. 1-70.

Gordon, D.P., 1984, The marine fauna of New Zealand: Bryozoa: Gymnolaemata from the Kermadec Ridge: New Zealand Oceanographic Institute Memoir, v. 91, p. 1-198.

Gordon, D.P., 2011, Interim classification for Treatise. Version of September 2011. Unpublished.

Gray, J.E., 1848, List of the specimens of British animals in the collections of the British Museum. Part 1. Centrionae or radiated animals: London, Trustees of the British Museum, p. 91-151.

Guha, A.K., and Gopikrishna, K., 2005, Some fossil anascan bryozoan taxa from the Tertiary sequences of western Kachchh, Gujarat: Journal of the Palaeontological Society of India, v. 50, p. 135-151.

Guha, A.K., and Gopikrishna, K., 2007, Some fossil ascophoran bryozoan taxa from Tertiary sequences of western Kachchh, Gujarat: Journal of the Palaeontological Society of India, v. 52, p. 195-222.

Hamdane, A., and Moissette, P., 2002, Bryozoan distribution in a Messinian coral reef complex of western Algeria, in Wyse-Jackson, P.N., Buttler, C.J., and Spencer-Jones, M., eds., Bryozoan Studies 2001: Tokyo, Lisse, Abingdon, Exton, A.A. Balkema Publishers, p. 141-149.

Harmelin, J.G., 2006, The Puellina flabellifera species complex: a remarkable example of worldwide species radiation in cribrimorph bryozoans: Courier Forschungsinstitut Senckenberg, v. 257, p. 73-92.

Harmer, S.F., 1926, The Polyzoa of the Siboga Expedition, 2. Cheilostomata Anasca: Siboga Expedition Reports, v. 28b, p. 183-501

Hayward, P.J., and McKinney, F.K., 2002, Northern Adriatic Bryozoa from the vicinity of Rovinj, Croatia: Bulletin of the American Museum of Natural History, v. 270, p. 1-139.

Hendy, A.J.W., Jones, D.S., Moreno, F., Zapata, V., and Jaramillo, C., 2015 , Neogene molluscs, shallow-marine paleoenvironments and chronostratigraphy of the Guajira Peninsula, Colombia: Swiss Journal of Palaeontology, v. 134 , p. $45-75$.

Herrera-Cubilla, A., and Jackson, J.B.C., 2014, Phylogeny of genus Cupuladria (Bryozoa, Cheilostomata) in the Neogene of tropical America: Journal of Paleontology, v. 88, p. 851-894.

Hincks, T., 1879, On the classification of the British Polyzoa: Annals and Magazine of Natural History, v. 5, p. 153-164.

Hincks, T., 1880, Contributions towards a general history of the marine Polyzoa. Part I. Madeiran Polyzoa: Annals and Magazine of Natural History, ser. 5 , v. 6, p. 69-80.

Hincks, T., 1884, Contributions towards a general history of the marine Polyzoa. XII. Polyzoa from India (coast of Burmah). Part XIII. Polyzoa from Victoria and Western Australia: Annals and Magazine of Natural History, ser. 5, v. 13 , p. $356-369$.

Insalaco, E., 1998, The descriptive nomenclature and classification of growth fabrics in fossil scleractinian reefs: Sedimentary Geology, v. 118, p. $159-186$.

Jackson, J.B.C., and Johnson, K.G., 2001, Measuring past biodiversity: Science, v. 293, p. 2401-2404.

Jackson, J.B.C., and Winston, J.E., 1982, Ecology of cryptic coral reef communities. I. Distribution and abundance of major groups of encrusting organisms: Journal of Experimental Marine Biology and Ecology, v. 57, p. $135-147$

Jackson, J.B.C., Winston, J.E., and Coates, A.G., 1985, Niche breadth, geographic range, and extinction of Caribbean reef-associated cheilostome Bryozoa and Scleractinia: Proceedings of the Fifth International Coral Reef Congress, v. 4, p. 151-158.

Jaramillo, C., Sepulchre, P., Cardenas, D., Correa-Metrio, A., Moreno, J.E., Trejos, R., Vallejo, D., Hoyos, N., Martínez, C., Carvalho, D., Escobar, J., Oboh-Ikuenobe, F., Prámparo, M.B., and Pinzón, D., 2020, Drastic vegetation change in the Guajira Peninsula (Colombia) during the Neogene: Paleoceanography and Paleoclimatology, v. 35, e2020PA003933, https://doi.org/ 10.1029/2020PA003933.

Jerez-Jaimes, J.H., Cetina-Tarazona, M.A., and Araque-Gomez, C.N., 2013, Primer registro del briozoo Stomatopora aff. cunningtoni (Orden: 
Cyclostomata, Familia: Stomatoporidae) en el Cretácico inferior de Colombia: Boletín de Geología, v. 35, p. 45-51.

Johnston, G., 1847, A History of British Zoophytes Vol. 1: London, Van Voorst, $499 \mathrm{p}$.

Jullien, J., 1882, Note sur une nouvelle division des Bryozoaires Cheilostomiens: Bulletin de la Société Zoologique de France, v. 6, p. 271-285.

Jullien, J., 1886, Les Costulidées, nouvelle famille de Bryozoaires: Bulletin de la Société zoologique de France, v. 11, p. 601-620.

Jullien, J., 1888, Bryozoaires. Mission Scientifique du Cap Horn 1882-1883. Zoologie, v. 6: Paris, Gauthier-Villars et Fils, p. 1-92.

Kirkpatrick, R., 1888, Polyzoa of Mauritius: Annals and Magazine of Natural History, v. 6, p. 72-85.

Lagaaij, R., 1952, The Pliocene Bryozoa of the Low Countries and their bearing on the marine stratigraphy of the North Sea region: Mededelingen van de Geologische Stichting, v. 5, p. 6-233.

Lagaaij, R., 1963, New additions to the bryozoan fauna of the Gulf of Mexico: Institute of Marine Science Publication, v. 9, p. 181-236.

Lamarck, J.B.P.A., 1816, Les Polypes. Histoire Naturelle des Animaux sans Vertèbres: Paris, Verdiere, v. 2, 568 p.

Lamouroux, J.V.F., 1821, Exposition Méthodique des Genres de l'ordre des Polypiers, avec leur description et celles des principales espèces figurées dans 84 planches, les 63 premièrs appartenant a l'Histoire naturelle des zoophytes d'Ellis et Solander: Paris, V. Agasse, 115 p.

Lang, W. D., 1917, On some new Cenomanian and Turonian Polyzoa: Geological Magazine, v. 4, p. 256-258.

Larwood, G.P., 1973, New species of Pyripora d'Orbigny from the Cretaceous and the Miocene, in Larwood, G.P., ed. Living and Fossil Bryozoa: London, Academic Press, p. 463-473.

Li, Z.P., 1990, Bryozoaires de Montbrison-Fontbonau (Drome) et comparison avec les autres faunes Miocenes du Bassin Rhodanien meridional: Nouvelles Archives du Museum d'Histoire Naturelle Lyon, v. 27, p. 1-126.

Lonsdale, W., 1845, Account of six species of Polyparia obtained from Timber Creek, New Jersey: The Quarterly Journal of the Geological Society of London, v. 1, p. 65-75.

Marcus, E., 1949, Some Bryozoa from the Brazilian coast: Comunicaciones Zoológicas del Museo de Historia Natural de Montevideo, v. 3, p. 1-33.

Marcus, E., 1955, Notas sôbre briozoos marinhos brasilieros: Arquivos do Museu Nacional do Rio de Janiero, v. 42, p. 273-342.

Martha, S.O., Taylor, P.D., and Rader, W.L., 2019, Early Cretaceous cyclostome bryozoans from the early to middle Albian of the Glen Rose and Walnut formations of Texas, USA: Journal of Paleontology, v. 93, p. 244-259.

McGuirt, J.W., 1941, Louisiana Tertiary Bryozoa: Geological Bulletin, Louisiana State Department of Conservation, v. 21, p. 1-74.

McNair, A.H., 1940, Devonian Bryozoa from Colombia: Bulletins of American Paleontology, v. 25, p. 113-146.

Milne-Edwards, H., 1838, Mémoire sur les Crisies, les Hornères, et plusieurs autres Polypes vivants ou fossiles dont l'organisation est analogue à celle des Tubulipores: Annales des Sciences Naturelles, Zoologie (sér. 2), v. 9, p. 193-238.

Moissette, P., Dulai, A., Escarguel, G., Kazmer, M., Mueller, P., and SaintMartin, J.P., 2007, Mosaic of environments recorded by bryozoan faunas from the Middle Miocene of Hungary: Palaeogeography, Palaeoclimatology, Palaeoecology, v. 252, p. 530-556.

Moll, J.P.C., 1803, Eschara, ex zoophytorum, seu, phytozoorum ordine pulcherrimum ac notatu dignissimum genus, novis speciebus auctum, methodice descriptum et iconibus ad naturam delineatis illustratum: Camesiniana, Vindobonae, $70 \mathrm{p}$.

Moreno, F., Hendy, A.J.W., Quiroz, L., Hoyos, N., Jones, D.S., Zapata, V., Zapata, S., Ballen, G.A., Cadena, E., Cárdenas, A.L., Carrillo-Briceño, J.D., Carrillo, J.D., Delgado-Sierra, D., Escobar, J., Martínez, J.I., Martínez, C., Montes, C., Moreno, J., Pérez, N., Sánchez, R., Suárez, C., VallejoPareja, M.C., and Jaramillo, C., 2015, Revised stratigraphy of Neogene strata in the Cocinetas Basin, La Guajira, Colombia: Swiss Journal of Palaeontology, v. 134, p. 5-43.

Moyano, H.I., 1991， Bryozoa marinos chilenos VIII. Una síntesis zoogeográfica con consideraciones sistemáticas y la descripción de diez especies y dos géneros nuevos: Gayana Zoología, v. 55, p. 305-389.

Nikulina, E., and Taylor, P.D., 2010, Two new species of Electra (Bryozoa, Cheilostomata) from the Miocene of the Aquitaine Basin, France: Geobios, 43, p. $219-224$.

NMiTA Database, 1996-2016, Neogene Marine Biota of Tropical America: https://fossils.its.uiowa.edu/database/bryozoa/brymnsc.htm [Nov 2019]

Norman, A.M., 1903, Notes on the natural history of East Finmark. Polyzoa: Annals and Magazine of Natural History (ser. 7), v. 11, p. 567-598.

O'Dea, A., 2009, Relation of form to life habit in free-living cupuladriid bryozoans: Aquatic Biology, v. 7, p. 1-18.

O'Dea, A., Herrera-Cubilla, A., Fortunato, H., and Jackson, J.B.C., 2004, Life history variation in cupuladriid bryozoans from either side of the Isthmus of Panama: Marine Ecology Progress Series, v. 280, p. 145-161.
Osburn, R.C., 1940, Bryozoa of Porto Rico with a resume of West Indian Bryozoan fauna: Scientific Survey of Porto Rico and the Virgin Islands, v. 16, p. $321-486$.

Osburn, R.C., 1950, Bryozoa of the Pacific coast of America, part 1, Cheilostomata-Anasca: Report of the Allan Hancock Pacific Expeditions, v. 14 , p. $1-269$.

Osburn, R.C., 1953, Bryozoa of the Pacific coast of America, part 3, Cyclostomata, Ctenostomata, Entoprocta and Addenda: Report of the Allan Hancock Pacific Expeditions v. 14, p. 613-841.

Pouyet, S., 2000, Les bryozoaires cheilostomes du Neogene betique (SE Espagne): Revista Española de Paleontología, v. 15, p. 181-202.

Ramalho, L.V., Távora, V.A., Tilbrook, K.J., and Zágoršek, K., 2015, New species of Hippopleurifera (Bryozoa, Cheilostomata) from the Miocene Pirabas Formation, Pará state, Brazil: Zootaxa, v. 3999, p. 125-134.

Ramalho, L.V., Távora, V.A., and Zágoršek, K., 2017, New records of the Bryozoan Metrarabdotos from the Pirabas Formation (Lower Miocene), Pará State, Brazil: Palaeontologia Electronica, v. 20.2.32A, p. 1-11, https://doi. org/10.26879/704

Ramalho, L.V., Taylor, P.D., Moraes, F.C., Moura, R., Amado-Filho, G.M., and Bastos, A.C., 2018, Bryozoan framework composition in the oddly shaped reefs from Abrolhos Bank, Brazil, southwestern Atlantic: taxonomy and ecology: Zootaxa v. 4483, p. 155-186.

Ramalho, L.V., Serrano, F., Rueda, J. L., Távora, V.A., and Zágoršek, K., 2019, New update on the bryozoan assemblage of the Miocene Pirabas Formation, Brazil, in Schmidt, R., Reid, C.M., Gordon, D.P., Walker-Smith, G., and Percival, I.P., eds., Bryozoan Studies 2016: Sydney, Australasian Palaeontologists, p. 109-114.

Renz, O., 1960, Geologia de la parte sureste de la Península de La Guajira: Memorias del III Congreso Geológico Venezolano: Boletin Geológico, Publicación Especial No. 3, p. 317-347.

Reuss, A.E., 1848, Die fossilen Polyparien des Wiener Tertiärbeckens: Haidingers Naturwissenschaftlichen Abhandlungen, vol. 2, p. 1-109.

Reuss, A.E., 1869, Die fossilen Anthozoen und Bryozoen der Schichtengruppe von Crosara: Denkschriften der Kaiserlichen Akademie der Wissenschaften, v. 29 , p. $215-298$

Rollins, J., 1965, Stratigraphy and structure of the Guajira Peninsula, NorthWestern Venezuela and Northeastern Colombia: University of Nebraska Studies, v. 30, p. 1-102.

Rosso, A., Beuck, L., Vertino, A., Sanfilippo, R., and Freiwald, A., 2018, Cribrilinids (Bryozoa, Cheilostomata) associated with deep-water coral habitats at the Great Bahama Bank slope (NW Atlantic), with description of new taxa: Zootaxa, v. 4524, p. 401-439.

Rosso, A., Di Martino, E., and Ostrovsky, A.N., 2020, Cribrilinid bryozoans from Pleistocene Mediterranean deep-waters, with the description of new species: Journal of Paleontology, p. 1-23, https://doi.org/10.1017/jpa.2020.93.

Sandberg, P.A., 1962, New cheilostome Bryozoa from the Miocene of the Dominican Republic: Micropaleontology, v. 8, p. 61-66.

Santodomingo, N., Novak, V., Pretković, V., Marshall, N., Di Martino, E., Lo Giudice-Capelli, E., Rösler, A., Reich, S., Braga, J.C., Renema, W., and Johnson, K.G., 2015, A diverse patch reef from turbid habitats in the middle Miocene (East Kalimantan, Indonesia): Palaios, v. 30, p. 128-149.

Schopf, T.J.M., 1974, Ectoprocts as associates of coral reefs: St. Croix, U.S. Virgin Islands: Proceedings of the International Coral Reef Symposium, v. 2 , p. $353-356$

Scolaro, R.J., 1968, Paleoecology of the Bryozoa of the Chipola Formation, Clarksville area, Florida [Ph.D. thesis]: New Orleans, Tulane University, $253 \mathrm{p}$.

Silva-Tamayo, J.C., Lara, M.E., Nana Yobo, L., Erdal, Y.D., Sanchez, J., and Zapata-Ramírez, P.A., 2017, Tectonic and environmental factors controlling on the evolution of Oligo-Miocene shallow marine carbonate factories along a tropical SE Circum-Caribbean: Journal of South American Earth Sciences, v. 78, p. 213-237.

Smitt, F.A., 1873, Floridan Bryozoa collected by Count L.F. de Pourtales, Part 2: Kongliga Svenska Vetenskaps-Akademiens Handlingar, v. 11, p. 1-83.

STRI Database, 2017, Smithsonian Tropical Research Institute. The bryozoans of the Pacific. https://biogeodb.stri.si.edu/briozoos [Nov 2019]

Taylor, P.D., and Di Martino, E., 2014, Why is the tropical Cenozoic fossil record so poor for bryozoans? in Rosso, A., Wyse-Jackson, P.N., and Porter, J., eds., Bryozoans Studies 2013: Studi Trentini di Scienze Naturali, v. 94, p. $249-257$.

Taylor, P.D., and Foster, T.S., 1998, Bryozoans from the Pliocene Bowden Shell Bed of Jamaica: Contributions to Tertiary and Quaternary Geology, v. 35, p. 63-83.

Taylor, P.D., and James, N.P., 2013, Secular changes in colony-forms and bryozoan carbonate sediments through geological history: Sedimentology, v. 60, p. $1184-1121$.

Taylor, P.D., and McKinney, F.K., 2006, Cretaceous Bryozoa from the Campanian and Maastrichtian of the Atlantic and Gulf Coastal Plains, United States: Scripta Geologica, v. 132, p. 1-346. 
Taylor, P.D., and Waeschenbach, A., 2015, Phylogeny and diversification of bryozoans: Palaeontology, v. 58, p. 1-15.

Taylor, P.D., and Zatoń, M., 2008, Taxonomy of the bryozoan genera Oncousoecia, Microeciella and Eurystrotos (Cyclostomata: Oncousoeciidae): Journal of Natural History, v. 42, p. 2557-2574.

Taylor, P.D., James, N.P., Bone, Y., Kuklinski, P., and Kyser, T.K., 2009, Evolving mineralogy of cheilostome bryozoans: Palaios, v. 24, p. 440-452

Taylor, P.D., Martha, S.O., and Gordon, D.P., 2018, Synopsis of 'onychocellid' cheilostome bryozoan genera: Journal of Natural History, v. 52, p. $1657-$ 1721.

Tilbrook, K.J., 1998, The species of Antropora Norman, 1903 (Bryozoa: Cheilostomatida), with the description of a new genus in the Calloporoidea: Records of the South Australian Museum, v. 31, p. 25-49.

Ulrich, E.O., and Bassler, R.S., 1907, Chapter 5. Branch Molluscoidea, in Weller, S., ed., A report on the Cretaceous paleontology of New Jersey. Based on the stratigraphic studies of George N. Knapp: Trenton, MacCrellish and Quigley, State Printers, p. 313-356.

van Beneden, P.J., 1850, Récherches sur les polypes bryozoaires de la Mer du Nord, et projet d'une classification des animaux de ce groupe: Bulletin de l'Academie Royale de Belgique, Classes des Sciences, v. 16, p. 644-658.

Vaughan, T.W., 1919, Fossil corals from Central America, Cuba and Porto Rico, with an account of the American Tertiary, Pleistocene, and Recent coral reef: United States National Museum Bulletin, v. 103, p. 189-524.

Vávra, N.R., 2012, The use of early Miocene bryozoan faunal affinities in the central Paratethys for inferring climatic change and seaway connections, in Ernst, A., Schäfer, P., and Scholz, J., eds. Bryozoan Studies 2010: Heidelberg, Springer, p. 401-418

Vieira, L.M., Spencer-Jones, M.E., Winston, J.E., Migotto, A.E., and Marques, A.C., 2014, Evidence for polyphyly of the genus Scrupocellaria (Bryozoa: Candidae) based on a phylogenetic analysis of morphological characters: PLoS ONE, v. 9, e95296, https://doi.org/10.1371/journal.pone.0095296.

Vigneaux, M., 1949, Révision des Bryozoaires néogènes du Bassin d'Aquitaine et essai de classification: Mémoires de la Société Géologique de France, v. 28, p. $1-153$.

Walter, B., 1970, Les Bryozoaires Jurassiques en France: Étude systématique. Rapports avec la stratigraphie et la paléoécologie: Documents des Laboratoires de Géologie de la Faculté des Sciences de Lyon, v. 35, p. 1-328.
Weisbord, N.E., 1973, New and little-known corals from the Tampa Formation of Florida: Geological Bulletin, State of Florida Department of Natural Resources, Division of Interior Resources, Bureau of Geology, v. 56, p. $1-157$.

Winston, J.E., 1984, Shallow-water bryozoans of Carrie Bow Bay, Belize: American Museum Novitates, v. 2799, p. 1-38.

Winston, J.E., 1986, An annotated checklist of coral-associated bryozoans: American Museum Novitates, v. 2859, p. 1-39.

Winston, J.E., 2005, Re-description and revision of Smitt's "Floridan Bryozoa" in the collection of the Museum of Comparative Zoology, Harvard University: Virginia Museum of Natural History Memoir, v. 7, p. 1-147.

Winston, J.E., 2016, Bryozoa of Floridan Oculina reefs: Zootaxa, v. 4071, p. 181.

Winston, J.E., and Cheetham, A.H., 1984, The Bryozoan Nellia tenella as a living fossil, in Eldredge, N., and Stanley, S., eds., Living Fossils: New York, Springer Verlag, p. 257-265.

Winston, J.E., and Jackson, J.B.C., 1984, Ecology of cryptic coral-reef communities. IV. Community development and life histories of encrusting cheilostome Bryozoa: Journal of Experimental Marine Biology and Ecology, v. 76, p. $1-21$.

Winston, J.E., and Vieira, L.M., 2013, Systematics of interstitial encrusting bryozoans from southeastern Brazil: Zootaxa, v. 3710, p. 101-146.

Winston, J.E., Vieira, L.M., and Woollacott, R.M., 2014, Scientific Results of the Hassler Expedition. Bryozoa. No. 2. Brazil: Bulletin of the Museum of Comparative Zoology, v. 161, p. 139-239.

Wood, S.V., 1844, Descriptive catalogue of the zoophytes of the Crag: Annals and Magazine of Natural History, v. 1, p. 10-21

Zágoršek, K., 2003, Upper Eocene Bryozoa from Waschberg Zone (Austria): Beiträge zur Paläontologie, v. 28, p. 101-263.

Zágoršek, K., 2010, Bryozoa from the Langhian (Miocene) of the Czech Republic. Part I: Geology of the studies sections, systematic decription of the Orders Cyclostomata, Ctenostomata, and "Anascan" Cheilostomata (Suborders Malacostega Levinsen, 1902 and Flustrina Smitt, 1868): Acta Musei Nationalis Pragae Series B-Historia Naturalis, v. 66, p. 1-136

Zágoršek, K., Ramalho, L.V., Berning, B., and Távora, V.A., 2014, A new genus of the family Jaculinidae (Cheilostomata, Bryozoa) from the Miocene of the tropical western Atlantic: Zootaxa, v. 3838, p. 98-112. 


\section{Appendix}

Appendix 1. List of bryozoans found in the Siamaná Formation (Cocinetas Basin in La Guajira Peninsula, Colombia). The collection is hosted at the Mapuka Museum of the Universidad del Norte, Barranquilla-Colombia. Specimens studied but not included in the descriptions because poorly preserved are indicated with an asterisk $(*)$.

\begin{tabular}{|c|c|c|c|c|c|c|c|c|}
\hline Familiy & Species & $\begin{array}{l}\text { Cataloge number } \\
\text { MUN-STRI }\end{array}$ & Locality & $\begin{array}{l}\text { Station } \\
\text { number }\end{array}$ & Type of colony & Substrate & $\begin{array}{l}\text { Number of } \\
\text { specimens }\end{array}$ & Coating \\
\hline Antroporidae & Antropora sp.* & 47629 & Arroyo Uitpa & 550005 & Encrusting & Porites sp. & 1 & Uncoated \\
\hline Antroporidae & Antropora guajirensis $\mathrm{n} . \mathrm{sp}$. & 47628 & Arroyo Uitpa & 550005 & Encrusting & Porites sp. & 1 & Coated \\
\hline Calloporidae & Copidozoum sp. indet. & 47627 & Arroyo Ekieps & 550012 & Encrusting & Colpophyllia willoughbiensis & 1 & Coated \\
\hline Candidae & Licornia sp. indet. & 47632 & Arroyo Ekieps & 550012 & Erect articulated & Acropora panamensis & 5 & Coated \\
\hline Candidae & Licornia sp. indet. & 47633 & Arroyo Ekieps & 550012 & Erect articulated & Acropora panamensis & 2 & Coated \\
\hline Cribrilinidae & Glabrilaria sp. indet. & 47646 & Arroyo Ekieps & 550013 & Encrusting & Mollusk shell & 1 & Coated \\
\hline Cribrilinidae & Cribrilaria multicostata $\mathrm{n} . \mathrm{sp}$. & 47653 & Arroyo Ekieps & 550013 & Encrusting & Acropora panamensis & 2 & Coated \\
\hline Cribrilinidae & Cribrilaria multicostata n. sp. & 47654 & Arroyo Ekieps & 550013 & Encrusting & Mollusk shell & 1 & Uncoated \\
\hline Cribrilinidae & Cribrilaria multicostata $\mathrm{n} . \mathrm{sp}$. & 47652 & Arroyo Ekieps & 550013 & Encrusting & Acropora panamensis & 1 & Coated \\
\hline Cribrilinidae & Cribrilaria multicostata n. sp. & 47655 & Arroyo Ekieps & 550013 & Encrusting & Acropora panamensis & 1 & Coated \\
\hline Cribrilinidae & Cribrilaria multicostata $\mathrm{n}$. sp. & 47656 & Arroyo Ekieps & 550013 & Encrusting & Acropora panamensis & 1 & Uncoated \\
\hline Cribrilinidae & Cribrilaria multicostata n. sp. & 47650 & Arroyo Ekieps & 550013 & Encrusting & Acropora panamensis & 1 & Coated \\
\hline Cribrilinidae & Cribrilaria multicostata $\mathrm{n} . \mathrm{sp}$. & 47651 & Arroyo Ekieps & 550013 & Encrusting & Acropora panamensis & 1 & Coated \\
\hline Cribrilinidae & Cribrilaria nixor $\mathrm{n} . \mathrm{sp}$. & 47657 & Arroyo Ekieps & 550013 & Encrusting & Acropora panamensis & 1 & Coated \\
\hline Cribrilinidae & Cribrilaria nixor $\mathrm{n} . \mathrm{sp}$. & 47658 & Arroyo Ekieps & 550013 & Encrusting & Acropora panamensis & 1 & Uncoated \\
\hline Cribrilinidae & Cribrilinidae* & 47659 & Arroyo Ekieps & 550013 & Encrusting & Acropora panamensis & 1 & Uncoated \\
\hline Cribrilinidae & Cribrilinidae* & 47660 & Arroyo Ekieps & 550013 & Encrusting & Acropora sp. & 1 & Uncoated \\
\hline Cribrilinidae & Cribrilinidae* & 47661 & Arroyo Ekieps & 550013 & Encrusting & Undetermined & 1 & Uncoated \\
\hline Cribrilinidae & Cribrilinidae* & 47662 & Arroyo Ekieps & 550013 & Encrusting & Mollusk shell & 1 & Uncoated \\
\hline Cribrilinidae & Cribrilinidae* & 47663 & Arroyo Ekieps & 550013 & Encrusting & Acropora panamensis & 1 & Uncoated \\
\hline Cribrilinidae & Cribrilinidae* & 47664 & Arroyo Ekieps & 550013 & Encrusting & Acropora panamensis & 1 & Uncoated \\
\hline Cribrilinidae & Cribrilinidae* & 47665 & Arroyo Uitpa & 550006 & Encrusting & Coraline algae over Porites sp. & 1 & Uncoated \\
\hline Cribrilinidae & Figularia bragai n. sp. & 47647 & Arroyo Ekieps & 550012 & Encrusting & Colpophyllia willoughbiensis & 1 & Coated \\
\hline Cribrilinidae & Figularia bragai n. sp. & 47648 & Arroyo Ekieps & 550013 & Encrusting & Acropora sp. & 1 & Uncoated \\
\hline Cribrilinidae & Figularia bragai n. sp. & 47649 & Arroyo Ekieps & 550013 & Encrusting & Porites baracoaensis & 1 & Uncoated \\
\hline Entalophoridae & Mecynoecia sp. indet. & 47624 & Arroyo Ekieps & 550013 & Erect rigid & Goniopora hilli & 3 & Uncoated \\
\hline Entalophoridae & Mecynoecia sp. indet. & 47623 & Arroyo Ekieps & 550013 & Erect rigid & Goniopora hilli & 1 & Coated \\
\hline Microporidae & Calpensia caribensis n. sp. & 47634 & Arroyo Ekieps & 550013 & Encrusting & Alveopora tampae & 1 & Uncoated \\
\hline Microporidae & Calpensia caribensis n. sp. & 47635 & Arroyo Ekieps & 550013 & Encrusting & Colpophyllia willoughbiensis & 1 & Coated \\
\hline Microporidae & Calpensia caribensis $\mathrm{n} . \mathrm{sp}$. & 47636 & Arroyo Ekieps & 550013 & Encrusting & Goniopora hilli & 1 & Uncoated \\
\hline Oncousoeciidae & Proboscina sp. indet. & 47626 & Arroyo Ekieps & 550013 & Encrusting & Acropora panamensis & 1 & Uncoated \\
\hline Oncousoeciidae & Proboscina sp. indet. & 47625 & Arroyo Ekieps & 550013 & Encrusting & Alveopora tampae & 1 & Coated \\
\hline Onychocellidae & Atoichos magnus n. gen. n. sp. & 47637 & Arroyo Ekieps & 550013 & Encrusting & Mollusk shell & 1 & Coated \\
\hline Onychocellidae & Smittipora sp. indet. & 47638 & Arroyo Uitpa & 550005 & Encrusting & Porites sp. & 1 & Coated \\
\hline Onychocellidae & Smittipora sp. indet. & 47639 & Arroyo Uitpa & 550005 & Encrusting & Porites sp. & 1 & Uncoated \\
\hline Poricellariidae & Poricellaria sp. indet. & 47645 & Arroyo Ekieps & 550012 & Erect articulated & Goniopora hilli & 2 & Coated \\
\hline Quadricellariidae & Nellia cf. N. tenella & 47630 & Arroyo Ekieps & 550012 & Erect articulated & Goniopora hilli & 3 & Coated \\
\hline Steginoporellidae & Gymnophorella hadra n. gen. n. sp. & 47641 & Arroyo Uitpa & 550006 & Encrusting & Porites sp. & 1 & Coated \\
\hline Steginoporellidae & Gymnophorella hadra n. gen. n. sp. & 47642 & Arroyo Uitpa & 550005 & Encrusting & Undetermined & 1 & Coated \\
\hline Steginoporellidae & Gymnophorella hadra n. gen. n. sp. & 47643 & Arroyo Uitpa & 550005 & Encrusting & Coraline algae over Porites sp. & 1 & Coated \\
\hline Steginoporellidae & Gymnophorella hadra n. gen. n. sp. & 47640 & Arroyo Uitpa & 550005 & Encrusting & Coraline algae over Porites sp. & 1 & Coated \\
\hline Steginoporellidae & Gymnophorella hadra n. gen. n. sp. & 47644 & Arroyo Uitpa & 550005 & Encrusting & Porites sp. & 1 & Coated \\
\hline
\end{tabular}

Accepted: 24 January 202 